\title{
Advances in Understanding the LncRNA-Mediated Regulation of the Hippo Pathway in Cancer
}

This article was published in the following Dove Press journal: OncoTargets and Therapy

\author{
Mengwei Wang* \\ Tianwei $\mathrm{Xu}^{*}$ \\ Wenyan Feng* \\ Junxia Liu \\ Zhaoxia Wang (D)
}

Cancer Medical Center, The Second Affiliated Hospital of Nanjing Medical University, Nanjing, Jiangsu, People's Republic of China

*These authors contributed equally to this work
Correspondence: Zhaoxia Wang

Cancer Medical Center, The Second

Affiliated Hospital of Nanjing Medical

University, Jiangjiayuan Road I2 I\#,

Nanjing, People's Republic of China

Tel +86-25-58509810

Fax +86-25-58509994

Email wangzhaoxia@njmu.edu.cn

\begin{abstract}
Long noncoding RNAs (lncRNAs) are a class of RNA molecules that are longer than 200 nucleotides and cannot encode proteins. Over the past decade, IncRNAs have been defined as regulatory elements of multiple biological processes, and their aberrant expression contributes to the development and progression of various malignancies. Recent studies have shown that lncRNAs are involved in key cancer-related signaling pathways, including the Hippo signaling pathway, which plays a prominent role in controlling organ size and tissue homeostasis by regulating cell proliferation, apoptosis, and differentiation. However, dysregulation of this pathway is associated with pathological conditions, especially cancer. Accumulating evidence has revealed that lncRNAs can modulate the Hippo signaling pathway in cancer. In this review, we elaborate on the role of the Hippo signaling pathway and the advances in the understanding of its lncRNA-mediated regulation in cancer. This review provides additional insight into carcinogenesis and will be of great clinical value for developing novel early detection and treatment strategies for this deadly disease.
\end{abstract}

Keywords: IncRNAs, Hippo pathway, cancer, tumorigenesis, prognosis

\section{Introduction}

Cancer is a major disease that threatens human health and life, and its incidence and mortality are increasing rapidly. According to global cancer statistics, approximately 18.1 million new cancer cases were diagnosed and 9.6 million cancerrelated deaths occurred worldwide in 2018, and the global burden of cancer has since increased. ${ }^{1}$ Cancer has the biological characteristics of abnormal cell differentiation and proliferation, uncontrolled cell growth, invasiveness and metastasis, and its development involves genetic alterations in specific genes and their related signaling pathways. ${ }^{2,3}$ Accumulating studies have identified several canonical signaling pathways that are frequently genetically altered in cancer, such as the Notch, cell cycle, PI3K-Akt-mTOR, RTK-RAS, TGF $\beta$, p53, and $\beta$-catenin/Wnt pathways, as well as the Hippo signaling pathway. ${ }^{4}$ Drugs that target some of these wellknown cancer pathways, such as RTKIs that target the RTK-mediated signaling pathways, have been approved and demonstrated clinical efficacy. ${ }^{5}$ It is hypothesized that signaling pathways play an important role in the development of cancer and provide new avenues for therapeutic intervention.

The Hippo signaling pathway was initially discovered in a genetic screen for genes that inhibit tissue growth in Drosophila. ${ }^{6,7}$ The Hippo pathway is a conserved signaling cascade that controls tissue growth and organ size during development. Later, studies showed that the Hippo signaling pathway also exists and is highly conserved in 
mammals. ${ }^{8}$ Similar to other key cancer pathways, the Hippo pathway is involved in coordinating diverse cellular processes, including cell proliferation, apoptosis, and differentiation. It also participates in stem cell self-renewal and tissue regeneration and mediates immune responses and cell competition, which play a pivotal role in the homeostatic control of multicellular organisms. ${ }^{9-11}$ However, dysregulation of this pathway appears to be associated with various pathological conditions, especially cancer. ${ }^{12}$

Long noncoding RNAs (lncRNAs) are defined as a class of RNA molecules that are longer than 200 nucleotides (nt). In the last decade, IncRNAs have been reported to exert crucial effects on multiple biological processes by modulating gene expression via different mechanisms, such as epigenetic, transcriptional and posttranscriptional regulation, depending on their subcellular location. ${ }^{13}$ At the epigenetic level, lncRNAs regulate gene expression through DNA methylation, histone modification, and chromatin remodeling; ${ }^{14}$ at the transcriptional level, lncRNAs can interact directly with DNA or recruit transcription factors to regulate gene transcription; ${ }^{15}$ at the posttranscriptional level, lncRNAs usually interact with proteins to regulate their function and localization or with mRNAs to regulate their splicing, translation and stability. In particular, a variety of lncRNAs can act as competing endogenous RNAs (ceRNAs) to sponge microRNAs (miRNAs), thus reducing their regulatory effect on target mRNAs $^{16}$ (Figure 1). In addition, the dysregulation of IncRNAs has been found to be closely associated with the growth, proliferation, invasion, metastasis and angiogenesis of tumor cells. ${ }^{17-19}$ LncRNAs can function as oncogenes or tumor suppressors to regulate cancer-related signaling pathways either directly or indirectly, thereby influencing the development and progression of various human cancers. ${ }^{20,21}$ For instance, upregulation of the IncRNA MALAT1 can contribute to the proliferation and cisplatin resistance of gastric cancer cells by regulating the PI3K/Akt pathway. ${ }^{22}$ Recently, emerging evidence has indicated that lncRNAs are also involved in the regulation of the Hippo signaling pathway, ${ }^{23}$ but no detailed summary of this role has been presented.

Here, we elaborate on the role of the Hippo signaling pathway and the advances in the understanding of its lncRNA-mediated regulation in cancer. This study provides additional insight into carcinogenesis and will be of great clinical value for developing novel early detection and treatment strategies for cancer.

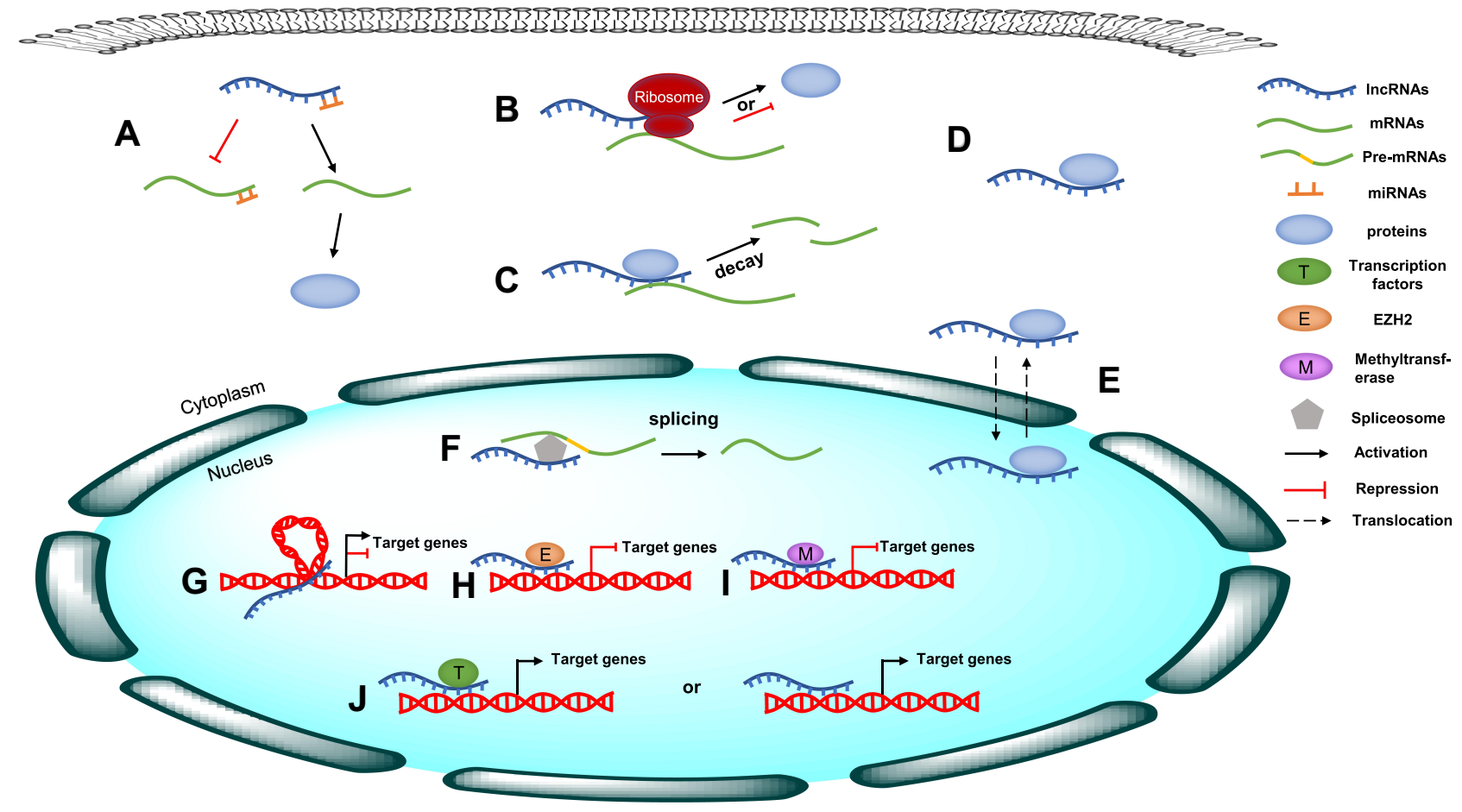

Figure I The molecular mechanism of IncRNAs. (A) LncRNAs act as ceRNAs to sponge specific miRNAs, thus reducing their regulatory effect on target mRNAs. (B) LncRNAs interact with mRNAs to regulate their translation. (C) LncRNAs regulate mRNA stability. (D) LncRNAs interact with proteins to regulate their function. (E) LncRNAs regulate the localization of proteins. (F) LncRNAs interact with mRNAs to regulate their splicing. (G) IncRNAs regulate gene expression through chromatin remodeling. (H) IncRNAs regulate gene expression through histone modification. (I) IncRNAs regulate gene expression through DNA methylation. (J) IncRNAs regulate gene transcription through recruiting transcription factors or interacting directly with DNA. 


\section{General Overview of the Hippo \\ Pathway}

The heart of the Hippo pathway includes the core kinases and downstream effectors. In mammals, the core kinase components of the Hippo pathway comprise the serine/ threonine kinases MST1/2 (also known as STK4/3), large tumor suppressor kinase 1/2 (LATS1/2), and their adaptor proteins SAV1 and MOB1. ${ }^{24-26}$ The downstream effectors of the pathway include two transcriptional coactivators, yes-associated protein (YAP) and its paralog transcriptional coactivator with PDZ-binding motif (TAZ). Due to the lack of a DNA-binding domain, YAP/TAZ mainly interacts with transcriptional factors such as TEA domain family members (TEADs), the key DNA-binding platforms for YAP/TAZ, to regulate target gene expression. ${ }^{27-29}$ Mechanistically, when the Hippo pathway is activated, MST1/2 complexes with SAV1 to phosphorylate and activate the LATS1/2 kinases, which then form a complex with their regulatory protein MOB1. The activated LATS1/2-MOB1 complex in turn phosphorylates YAP/TAZ and sequesters it in the cytoplasm by promoting its binding with 14-3-3 or degrading it in a ubiquitinproteasome-dependent manner. ${ }^{30,31}$ Conversely, when the Hippo pathway is inactivated, dephosphorylated YAP/TAZ translocate into the nucleus, where they bind to and activate TEADs to initiate target gene transcription and promote cell survival, proliferation and self-renewal ${ }^{10,29}$ (Figure 2). In addition to interacting with TEADs, YAP/ TAZ can also interact with other transcription factors, including p73, SMADs, TBX5, Runx1/2, ErbB4, and Pax3, to regulate the transcription of target genes. ${ }^{32}$ In summary, as the key effectors of the Hippo pathway, phosphorylated YAP/TAZ represent the major players.

The Hippo signaling pathway has been identified as a tumor suppressor pathway, because the loss of core Hippo kinases that suppress YAP/TAZ results in an overgrowth phenotype. ${ }^{33}$ To date, many studies have confirmed that the expression of YAP/TAZ is upregulated in various cancers and contributes to the tumorigenesis and development of these cancers by regulating cell proliferation, metastasis, and epithelial-mesenchymal transition (EMT). ${ }^{34-36}$ However, some studies reported

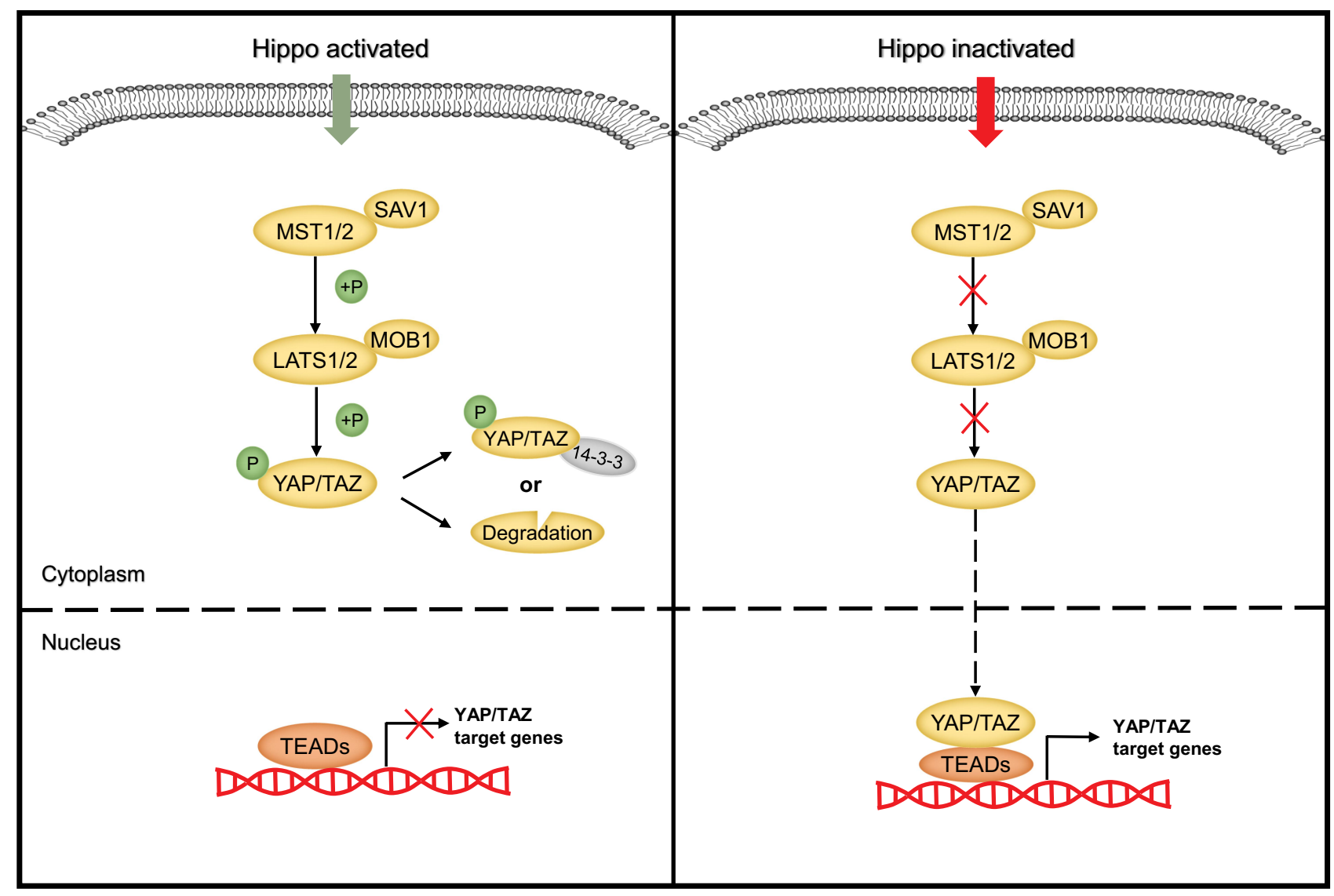

Figure 2 The molecular mechanism of the Hippo signaling cascade. 
that YAP can be phosphorylated by other kinases to exert the opposite effect. For example, YAP1 phosphorylation mediated by the tyrosine kinase YES1 can induce embryonic stem cell self-renewal. ${ }^{37}$ Moreover, in some hematological malignancies, YAP promotes cell apoptosis. ${ }^{38}$ These findings suggest that the Hippo-YAP signaling pathway can exhibit a dual role in carcinogenesis and cancer suppression. Therefore, a better understanding of the upstream regulators of the Hippo pathway is crucial for understanding tumorigenesis.

Studies have shown that the Hippo pathway can respond to a broad range of extracellular and intracellular signals, including cell-cell adhesion, apical-basal polarity, changes in cell shape and size, junctional complexes, G protein-coupled receptor (GPCR) stimulation, and the cellular energy status. ${ }^{39-43}$ To date, more than 20 molecules have been found to regulate the activity of the core components of the Hippo signaling pathway. ${ }^{44}$ For instance, the apical membrane-associated FERM domain protein Merlin (NF2 in mammals) acts as an important upstream inhibitor of YAP/TAZ, possibly by directly binding to LATS and recruiting it to the cell membrane, where it is activated by the Hippo kinase complex, or by indirectly promoting the assembly of protein scaffolds, for example, by forming a complex with Expanded (Ex) and the WW domain-containing protein Kibra that allows LATS activation. ${ }^{45,46}$ Moreover, cell junction proteins, such as angiomotin (AMOT) and E-cadherin, have been confirmed to be regulators or interacting partners of Hippo kinases. ${ }^{47,48}$ In addition, FAT tumor suppressor homolog 4 (FAT4), a member of the atypical cadherin family, can regulate Hippo-YAP pathway activity by acting as a signal receptor to transduce signals produced by extracellular stimulation into cells. ${ }^{49}$ In addition to the abovementioned regulatory proteins, many other molecules, including $\mathrm{MAP} /$ microtubule affinity-regulating kinases 1-4 (MARK1-4), RAS association domain-containing family protein (RASSF), FERM domain-containing 6 (FRMD6), the apical transmembrane protein Crumbs (Crb), the Scribble (Scrib) complex (Scrib/Dlg/Lgl), and so on, have been reported to modulate the Hippo pathway. ${ }^{50-54}$

Recently, accumulating evidence has clarified that lncRNAs also participate in Hippo pathway regulation at different subcellular levels depending on their localization. They function as upstream regulators and directly or indirectly target the core components of the Hippo pathway, including MST1/2, LATS1/2 and YAP/TAZ. On the one hand, nuclear lncRNAs can modulate the transcription of the key Hippo kinases or their upstream regulators through diverse mechanisms, including methyltransferasemediated methylation, chromatin remodeling, and transcription factor recruitment. ${ }^{55-58}$ On the other hand, cytoplasmic lncRNAs can act as ceRNAs to sponge specific miRNAs, such as miR-200a-3p and miR-497-5p. ${ }^{59,60}$ In addition, IncRNAs can directly bind to Hippo core proteins to control their subcellular localization or mediate the interactions between them. For example, the lncRNA B4GALT1-AS1 can directly bind to YAP to promote its nuclear translocation, while the lncRNA LEF1-AS1 directly interacts with the LATS1 protein, abolishing the interaction between LATS1 and MOB and leading to inactivation of the Hippo pathway. ${ }^{61,62}$ LncRNAs can also indirectly influence the Hippo pathway by interacting with the Hippo regulatory proteins. For instance, the lncRNA UCA1 can inactivate the Hippo signaling pathway by binding to AMOT $^{63}$ (Figure 3 ).

\section{LncRNAs Regulate the Hippo Pathway in Cancers Head and Neck Cancers}

Thyroid cancer (TC) is one of the most common malignancies in the head and neck and endocrine system. ${ }^{64}$ The global incidence of thyroid cancer has increased rapidly over the past few decades. ${ }^{65,66}$ LncRNAs have been reported to play an important role in the development of thyroid cancer, including in the steps of cell growth, survival and metastasis. ${ }^{67}$ Several studies have indicated that some lncRNAs modulate cell growth via the Hippo signaling pathway. Qin et $\mathrm{al}^{68}$ identified the lncRNA MIR22HG as a prognostic biomarker for thyroid cancer by analyzing data from the TCGA and GEO databases; MIR22HG was downregulated in thyroid cancer, and this downregulation was related to a poor survival outcome. Mechanistically, MIR22HG was shown through bioinformatics analysis to be associated with the Hippo signaling pathway in thyroid cancer. Yang et $\mathrm{al}^{69}$ demonstrated that overexpression of the IncRNA TNRC6C-AS1 promotes the proliferation of thyroid cancer cells while inhibiting their autophagy and apoptosis. A further investigation conducted by Peng et $\mathrm{al}^{55}$ indicated that TNRC6C-AS1 is localized in the nucleus and that its overexpression significantly promotes the methylation of cytosine-phosphate-guanine $(\mathrm{CpG})$ islands in the STK4 promoter region via the recruitment of methyltransferases, thus downregulating the expression of STK4. 


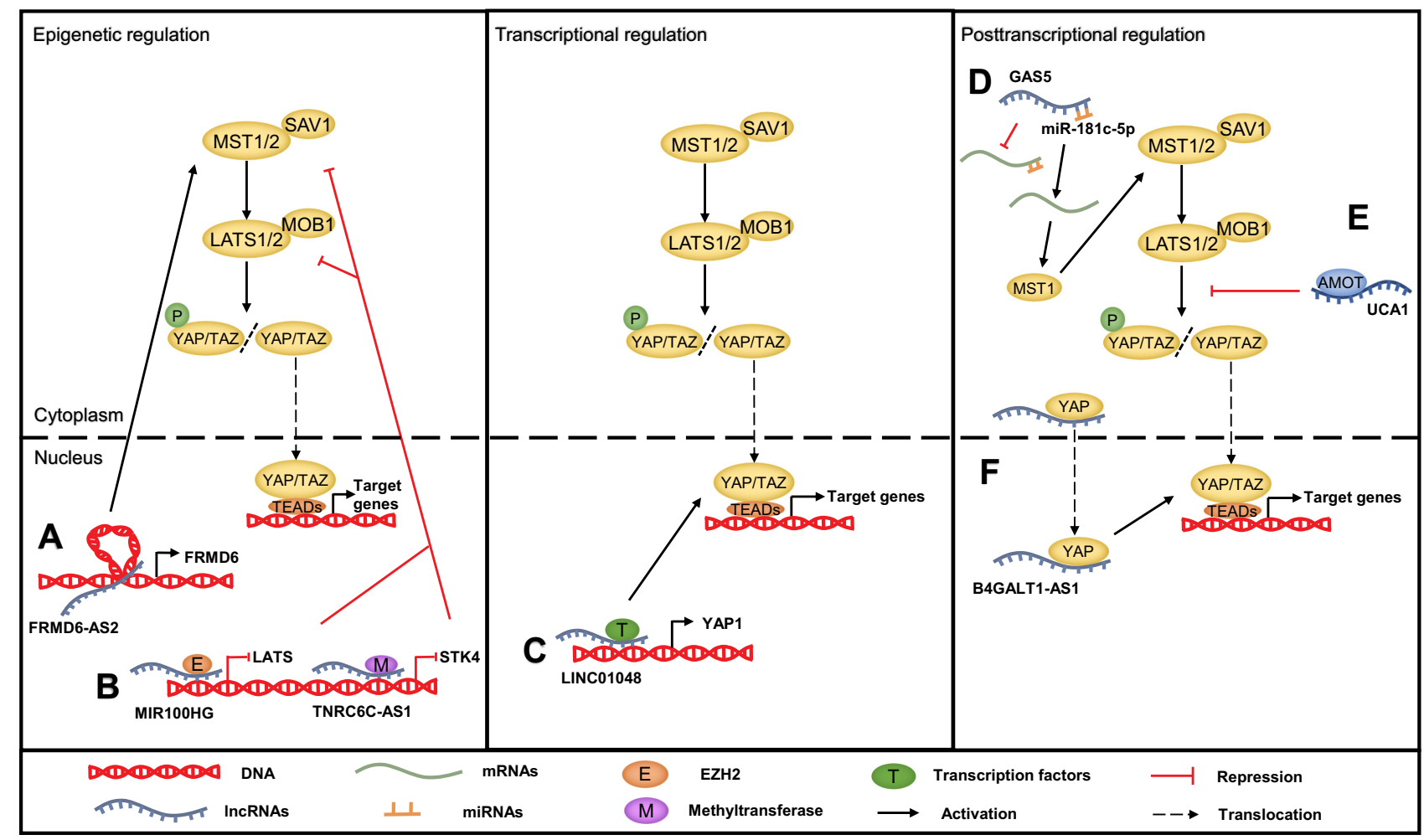

Figure 3 The mechanism of the IncRNA-mediated regulation of Hippo pathway in cancer. (A) LncRNAs regulate the Hippo pathway through chromatin remodeling, such as FRMD6-AS2. (B) LncRNAs regulate the Hippo pathway through recruiting methyltransferase or EZH2, such as TNRC6C-ASI and MIRI00HG. (C) LncRNA promoting Hippo gene transcription through recruiting transcription factor, such as LINC0I048. (D) LncRNAs act as ceRNAs to sponge specific miRNAs, such as GAS5. (E) LncRNAs interact with Hippo pathway components or upstream regulatory proteins to regulate their function, such as UCAI. (F) LncRNAs bind to proteins to control their subcellular localization, such as B4GALTI-ASI.

Simultaneously, the protein expression level of LATS1 and the phosphorylation of YAP were decreased. This finding suggests that TNRC6C-AS1 acts as an oncogene by inactivating the Hippo signaling pathway in thyroid cancer. Moreover, Wu et $\mathrm{al}^{59}$ found that the lncRNA SNHG15 is markedly upregulated in papillary thyroid cancer cell lines and tissues and that interference with SNHG15 can inhibit cell growth and migration. Further mechanistic investigation showed that SNHG15 can bind to miR-200a-3p as a ceRNA to upregulate the expression of YAP1, the downstream effector of the Hippo signaling pathway. In addition, the mRNA and protein expression levels of MST1/LATS1 were downregulated by SNHG15. Recently, Li et al ${ }^{70}$ reported that overexpressed UCA1 appreciably promotes TPC-1 thyroid cancer cell proliferation and EMT as well as suppresses TPC-1 cell apoptosis by sponging miR-15a, thus inhibiting the Hippo signaling pathway.

Head and neck squamous cell carcinoma accounts for $95 \%$ of head and neck cancers, among which oral squamous cell carcinoma (OSCC) is the most common. ${ }^{71,72}$ Zhang et $\mathrm{al}^{62}$ found that expression of the lncRNA LEF1AS1 was notably higher in OSCC tissues than in adjacent noncancerous tissues and that a high LEF1-AS1 expression level was associated with poor prognosis. Functional studies revealed that overexpressed LEF1-AS1 can promote cell survival, proliferation and migration, as well as inhibit apoptosis, by directly interacting with LATS1. Therefore, the binding of LATS1 to MOB is abolished, leading to Hippo signaling pathway inactivation and decreased YAP phosphorylation. Notably, accumulating evidence has suggested that IncRNAs also participate in regulating multidrug resistance. ${ }^{73,74}$ For example, Zhu et $\mathrm{al}^{75}$ reported that a high level of the lncRNA MRVI1-AS1 can increase the sensitivity of nasopharyngeal cancer (NPC) cells to paclitaxel in vitro and in vivo. In addition, this group confirmed that MRVI1-AS1 sensitizes NPC cells to paclitaxel by targeting miR-513a-5p and miR$27 b-3 p$ to upregulate activating transcription factor 3 (ATF3). Moreover, a positive feedback loop between ATF3 and MRVI1-AS1 has been identified, which promotes the expression of RASSF1, a regulatory factor of the Hippo signaling pathway, further decreasing the expression of TAZ at the posttranslational level. In summary, this finding indicates that MRVI1-AS1 can increase 
the paclitaxel sensitivity of NPC cells via the Hippo signaling pathway.

\section{Thoracic Cancers}

Lung cancer is the most common cancer with high morbidity and mortality. ${ }^{76}$ Qiao et $\mathrm{al}^{77}$ speculated that lncRNAs may play an important role in lung cancer in nonsmoking female patients. They used GEO2R, an interactive web analysis tool, to screened eight lncRNAs differentially expressed in lung cancer samples from three GEO datasets (GSE19804, GSE31210, and GSE31548). Additionally, 19 miRNAs and 38 mRNAs were associated with these 8 key lncRNAs. Functional and pathway enrichment analyses using the DAVID databases revealed that these target genes were related to the Hippo signaling pathway. Moreover, Zhao et $\mathrm{al}^{78}$ found that the expression level of the lncRNA NSCLCAT1 is elevated in non-small cell lung cancer (NSCLC) and that overexpressed NSCLCAT1 can facilitate the proliferation, migration and invasion of NSCLC cells while inhibiting their apoptosis. Further investigation revealed that NSCLCAT1 can inactivate the Hippo signaling pathway by repressing the transcription of the cadherin1 (CDH1) gene, which encodes E-cadherin, a cell-cell adhesion molecule that is expressed in the epithelium and has been determined to be a direct regulator of the Hippo pathway. ${ }^{79,80}$

Breast cancer is the leading cause of cancer-related mortality in women worldwide. ${ }^{81}$ Estrogen receptorpositive breast cancer accounts for approximately $70 \%$ to $80 \%$ of breast cancers, and antihormone therapy is the major clinical treatment strategy. However, approximately $30-50 \%$ of patients develop resistance to endocrine therapy. ${ }^{82,83}$ Liu et $\mathrm{al}^{84}$ found that breast cancer patients with high expression levels of the lncRNA CYTOR are likely exhibit tamoxifen resistance. The results of RTqPCR and dual luciferase reporter assays showed that CYTOR can directly bind to miR-125a-5p as a ceRNA to elevate the expression of serum response factor (SRF), which enhances the transcription of the Hippo effector TAZ by binding to its promoter. ${ }^{85}$ This study revealed that CYTOR contributes to the development of tamoxifen resistance by inactivating the Hippo signaling pathway. Moreover, several lncRNAs have been proven to promote the initiation and development of breast cancer by regulating the Hippo pathway. For instance, Li et $\mathrm{al}^{86}$ reported that the IncRNA ZFHX4-AS1 is upregulated in breast cancer. ZFHX4-AS1 is distributed mainly in the cytoplasm and negatively targets FAT4, which has been confirmed to act as a tumor suppressor in breast cancer. ${ }^{87}$ Furthermore, RT-qPCR and Western blot analysis showed that ZFHX4AS1 overexpression decreases FAT4 expression at both the mRNA and protein levels but promotes the expression of both YAP and TAZ. In addition, suppression of ZFHX4AS1 and the Hippo signaling pathway inhibits the proliferation, invasion and migration of breast cancer cells but promotes their apoptosis. Recently, Qiao et a ${ }^{88}$ observed that the expression of LINC00673 is elevated in breast cancer tissues and cell lines, while its downregulation can inhibit cell proliferation in vitro and in vivo. Mechanistically, LINC00673 was found to upregulate MARK4 by competing for miR-515-5p binding and further inactivating the Hippo signaling pathway. Moreover, MARK4 has been reported to function as an activator of YAP and TAZ by binding to MST and SAV. ${ }^{50}$ Another IncRNA, Linc-OIP5, was reported to act as an oncogenic regulator in breast cancer, and knockdown of Linc-OIP5 was found to significantly inhibit the proliferation, migration and invasion of breast cancer cells but induce their apoptosis via YAP1 downregulationmediated suppression of the Hippo signaling pathway. ${ }^{89}$ Additionally, a previous study showed that the lncRNA MAYA participates in the activation of YAP to stimulate the target gene connective tissue growth factor (CTGF), a signature gene that mediates breast cancer bone metastasis. ${ }^{90}$ The molecular mechanism underlying the effects of MAYA indicates that MAYA can directly bind to both the adaptor protein LLGL2 and the methyltransferase NSUN6 to form an RNA-protein complex. This complex further methylates MST1 at Lys59, which abolishes the kinase activity of MST1 and activates YAP. ${ }^{91}$ This result indicates the promising therapeutic value of MAYA against breast cancer bone metastasis.

\section{Abdominal Cancers}

Gastric carcinoma is one of the most frequently diagnosed cancers and the third leading cause of cancer death worldwide. ${ }^{1}$ A previous analysis of TCGA data showed that 3 lncRNAs (CYP4A22-AS1, AP000695.6, and RP11108M12.3) are differentially expressed in gastric cancer tissues compared to adjunct noncancerous tissues and are significantly related to the prognosis of patients with gastric cancer. Among these lncRNAs, AP000695.6 and RP11-108M12.3 are positively associated and CYP4A22AS1 is negatively associated with OS. In addition, functional enrichment analysis showed that these 3 key lncRNAs are associated mainly with the Hippo signaling 
pathway and involved in the cellular apoptotic process. This finding provides a useful prognostic biomarker for gastric cancer. ${ }^{92}$ Similarly, Liu et $\mathrm{al}^{60}$ reported that LINC00662 expression is significantly increased in gastric cancer tissues and that a high level of LINC00662 expression is strongly related to poor prognosis. Moreover, siRNA-mediated silencing of LINC00662 restores the response of gastric cancer cells to 5-fluorouracil (FU) and decreases their proliferation. Functional analysis revealed that LINC00662 can inhibit the Hippo signaling pathway by directly binding to miR-497-5p, which leads to upregulation of YAP1. In contrast, Chen et $\mathrm{al}^{93}$ found that lincRNA-p21 acts as a tumor suppressor in gastric cancer progression; a lower level of lincRNA-p21 was associated with a deeper invasion depth, higher grade, higher incidence of distant metastasis and more advanced TNM stage, suggesting the prognostic and therapeutic potential of this lncRNA in gastric cancer. Further investigation demonstrated that knockdown of lincRNA-p21 promotes proliferation and EMT in gastric cancer cell lines, possibly by increasing the protein and mRNA levels of YAP and facilitating YAP translocation from the cytoplasm to the nucleus in a Hippo-independent manner. Colorectal cancer remains a threat to human health, with increasing incidence rates in many countries. ${ }^{66}$ To understand the role of IncRNAs in colorectal cancer progression, Zhang et $\mathrm{al}^{94}$ used TCGA data to construct a ceRNA network comprising 62 lncRNAs, 30 miRNAs, and 59 mRNAs. The target genes in this lncRNA-associated ceRNA network significantly involved in oncogenic pathways, including the Hippo signaling pathway, suggesting that this pathway participates in colorectal cancer tumorigenesis. Moreover, a recent study ${ }^{61}$ reported that the IncRNA B4GALT1-AS1 is significantly upregulated in colon cancer cells. Both the in vitro and in vivo results indicated that knockdown of B4GALT1-AS1 can attenuate the stemness as well as the migration, invasion, and EMT processes in colon cancer cells. Ribonucleoprotein immunoprecipitation (RIP) analysis showed that the YAP protein is the direct target of B4GALT1-AS1; its transcriptional activity and nuclear translocation are suppressed by B4GALT1-AS1 knockdown, while its overexpression reverses B4GALT1-AS1 knockdown-induced inhibitory effects on colon cancer cells.

Liver cancer is the second most common cause of cancer-related death in males; HCC is the most common histologic type, accounting for approximately $80 \%$ of total liver cancer cases. ${ }^{95}$ The lncRNA PVT1 is located in the known cancer-related chromosomal region 8q24 and has been reported to function as an oncogene in many different cancers, including HCC. ${ }^{96-98}$ The results of a comprehensive analysis conducted by Zhang et al ${ }^{99}$ indicated that PVT1 is upregulated in HCC and is markedly related to patient sex, patient race, vascular invasion and pathological grade. Additionally, the ROC curve indicated the high diagnostic value of PVT1 in HCC. Furthermore, this group clarified that PVT1 may play a carcinogenic role in HCC possibly through modulating the Hippo pathway. Notably, the lncRNA UCA1 is another well-known unfavorable regulator in many malignancies. ${ }^{100,101}$ Consistent with these previous findings, Qin et $\mathrm{al}^{102}$ demonstrated that the expression of UCA1 is significantly upregulated in HCC tissues, and a meta-analysis showed that patients with a high level of UCA1 are more likely to have larger tumors, more advanced TNM stages and shorter OS times than those with a low level of UCA1. In addition, the results of in vitro experiments and KEGG pathway analysis indicated that UCA1 can promote the proliferation and inhibit the apoptosis of HCC cells via the Hippo signaling pathway. Ni et $\mathrm{al}^{103}$ found that expression of the lncRNA uc.134 is markedly downregulated in HCC samples and that a low expression level of uc.134 is closely related to poor prognosis. The results of in vivo and in vitro experiments indicated that uc. 134 exerts suppressive effects on the proliferative, invasive, and metastatic abilities of HCC cells. In addition, the findings indicated that uc.134 (nt 1408-1867) can directly bind to the CUL4A protein (aa 592-759), which is an E3 ubiquitin ligase that mediates the ubiquitination and degradation of LATS $1,{ }^{104}$ to form a RNP complex and retain CUL4A in the nucleus. Therefore, CUL4A-mediated ubiquitination and degradation of LATS1 in the cytoplasm is inhibited by uc.134, leading to the activation of the Hippo kinase and phosphorylation of YAP at Ser127. Hepatoblastoma (HB) is a common type of liver cancer in children classified into a variety of subgroups. ${ }^{105}$ By analyzing the GSE75271 dataset, Lv et al ${ }^{106}$ found LINC01314 overexpression in the subgroups with good prognosis. Further investigation demonstrated that overexpression of LINC01314 can reduce HepG2 cell proliferation, migration, and invasion via the Hippo pathway by increasing the expression of MTS1 and facilitating the phosphorylation of LATS1 and YAP.

Pancreatic cancer is one of the most lethal cancers, with a 5-year survival rate of approximately 5\%. ${ }^{107}$ Zhang et $\mathrm{al}^{108}$ found that consistent with its role in $\mathrm{HCC}$, 
UCA1 is closely associated with clinicopathological features, advanced clinical stage, and poor prognosis in pancreatic cancer, and functional investigation proved that it could enhance the migratory and invasive abilities of pancreatic cancer cells. Mechanistically, Zhang et al revealed that UCA1 upregulates YAP expression and promotes YAP nuclear translocation by interacting with MOB1, LATS1 and YAP to form a shielding complex, consequently enhancing the luciferase activity of TEAD. Moreover, Western blotting and qRT-PCR results showed the existence of a positive feedback loop between YAP and UCA1. Zhou et $\mathrm{al}^{109}$ claimed that the silencing of IncRNA MALAT1 contributes to the apoptosis of pancreatic cancer cells, accompanied by the attenuation of cell proliferation, migration, and invasion. Mechanistic investigation showed that MALAT1 interacts with the Hippo signaling pathway by downregulating the expression of LATS1 but upregulating the expression of YAP1. In addition, Gao et $\mathrm{al}^{110}$ focused on the impact of the lncRNA GAS5 on the chemoresistance of pancreatic cancer cells. They observed that the expression of GAS5 was markedly decreased in drug-resistant SW1990/GEM and PATU8988/ 5-FU cells, while miR-181c-5p showed the opposite trend. Further study showed that GAS5 overexpression improved the response of drug-resistant cells to gemcitabine (GEM) and 5-FU treatment and decreased cell viability, possibly by downregulating miR-181c-5p expression, subsequently increasing MST1 expression and YAP phosphorylation. This finding suggests that the GAS5/miR-181c-5p/Hippo signaling axis is a potential therapeutic target for conquering chemoresistance in pancreatic cancer.

\section{Central Nervous System Tumors}

Glioma is the most common type of primary brain tumor, accounting for $51.4 \%$ of all primary brain tumors, and glioblastoma is the most aggressive glioma, with high mortality in adults. ${ }^{111,112}$ In the GSE2223 and GSE59612 datasets Wang et al ${ }^{113}$ screened 712 lncRNAs dysregulated in glioblastoma multiforme compared with normal control tissues. Among these lncRNAs, DLEU1 was found to be significantly upregulated and to interact with 315 miRNAs and 105 mRNAs associated mainly with tumorigenesisrelated terms and pathways, including the Hippo signaling pathway. Su et $\mathrm{al}^{114}$ reported that overexpression of the lncRNA BDNF-AS markedly inhibits the proliferation, migration, and invasion of glioblastoma cells while increasing their apoptosis, suggesting that this lncRNA functions as a tumor suppressor in glioblastoma.
Furthermore, this group confirmed that BDNF-AS overexpression can decrease the expression level and mRNA half-life of retina and anterior neural fold homeobox 2 (RAX2), a member of the RAX transcription factor family that is essential for vertebrate eye development, through STAU1-mediated mRNA decay (SMD). ${ }^{115}$ In this process, imperfect base pairing between the Alu elements of BDNF-AS and RAX2 mRNA forms a SBS sequence, which is recognized by STAU1 and results in RAX2 decay. Subsequently, loss of RAX2 induces upregulation of discs large homolog 5 (DLG5), which is involved in maintaining cell polarity, ${ }^{116}$ further suppressing the malignant biological behaviors of glioblastoma cells by increasing the phosphorylation of YAP. Gong et $\mathrm{al}^{117}$ observed an increased level of the lncRNA KCNQ1OT1 in glioma tissues and cells, and knockdown of KCNQ1OT1 significantly inhibits the proliferation, migration and invasion but induces the apoptosis of glioma cells. In addition, functional studies showed that knockdown of KCNQ1OT1 can enhance the expression of miR-370, thus restoring the suppressive effects of miR-370 on the expression of Cyclin E2 (CCNE2), a member of the Cyclin E family that is involved in $\mathrm{G} 1 / \mathrm{S}$ transition of the cell cycle, ${ }^{118}$ which are mediated by targeting its 3'-UTR. Consequently, suppressed CCNE2 upregulates the phosphorylation of YAP, the core effector of the Hippo pathway. A recent $\operatorname{study}^{119}$ reported that LINC00473 was notably upregulated in glioma and associated with poor survival outcomes. Moreover, that group concluded that LINC00473 downregulated miR-195-5p by functioning as a ceRNA sponge, possibly promoting the expression of YAP1 and TEAD1 and thereby inducing the proliferation, invasion and migration of glioma cells, as well as inhibiting their apoptosis. Based on this finding, LINC00473 and miR-195-5p are believed to be therapeutic targets for glioma. Medulloblastoma (MB) is the most common pediatric malignant brain tumor; $\mathrm{MB}$ originates mainly from cerebellar granule neuron progenitors and has a dismal overall prognosis. ${ }^{120}$ Zhang et $\mathrm{al}^{121}$ found that overexpression of the lncRNA Nkx2-2as can impair the colony formation and invasion abilities and induce the apoptosis of MB cells; in addition, knockdown of Nkx22as exerts the opposite effects on these cells. Functional analysis demonstrated that $\mathrm{Nkx2} 2 \mathrm{2as}$ functions as a ceRNA to tether miR-103a/107 and miR-548m, resulting in sequestration of these miRNAs from their targets, such as B-cell translocation gene 2 (BTG2) and LATS1/2, which play a tumor-suppressive role in $\mathrm{MB}^{122}$ 
Consequently, the protein levels of BTG2 and LATS1/2 are increased in MB tissues and further lead to activation of the Hippo signaling pathway.

\section{Urogenital Cancers}

Renal cell carcinoma (RCC) is the most common form of kidney cancer, accounting for over $90 \%$ of renal malignancies. ${ }^{123}$ Accumulating evidence has shown that the IncRNA TUG1 acts as a tumor promoter in many cancer types, including RCC. ${ }^{124,125}$ Consistent with these previous studies, Liu et al ${ }^{126}$ reported that TUG1 is overexpressed in RCC tissues and positively regulates cell proliferation and migration. Mechanistically, TUG1 was proven to elevate YAP expression at both the mRNA and protein levels via a ceRNA mechanism by competing for miR-9 binding but was shown to have no influence on either the nuclear or cytoplasmic distribution of YAP. In addition, $\mathrm{Hu}$ et $\mathrm{al}^{127}$ clarified that interference with the lncRNA HOTAIR results in marked reductions in cell proliferation and migration in vitro and inhibits tumor growth in vivo. In addition, high levels of HOTAIR expression are closely related to poor patient outcomes, suggesting that HOTAIR may also act as an oncogenic regulator in RCC. Moreover, this group found a negative correlation between HOTAIR and SAV1. Further investigation indicated that HOTAIR promotes the malignant behavior of RCC cells by inactivating the Hippo pathway through direct binding to the SAV1 protein, the core component of the Hippo pathway.

Epithelial ovarian carcinoma (EOC) is the most lethal gynecological malignancy, with a 5-year survival rate of less than $50 \% .{ }^{128}$ Lin et al ${ }^{63}$ confirmed that UCA1 contributes to EOC tumorigenesis and development. Tumor growth was greatly suppressed in mice injected with UCA1 knockout (KO) ovarian cancer cells compared with mice injected with UCA1 wild-type (WT) ovarian cancer cells. Furthermore, this group confirmed that UCA1 can inhibit YAP phosphorylation at Ser127 and enhance YAP nuclear translocation by directly binding to AMOTp130, a known regulator of the Hippo pathway, ${ }^{129}$ to promote the interaction between AMOT and YAP, whereas the interaction between pLATS1/2 and YAP is abolished. Thus, the expression of YAP downstream target genes involved in tumor growth, such as CTGF and AXL, is increased. Uterine corpus endometrial cancer (UCEC) originates from the endometrial epithelium and is another of the most common gynecological malignancies. ${ }^{128}$ Bioinformatic analysis conducted by Wang et $\mathrm{al}^{56}$ showed that the expression of antisense lncRNA FRMD6-AS2 is reduced in UCEC, while high expression of FRMD6-AS2 predicts a better OS in patients with UCEC. In addition, the Hippo signaling pathway is dramatically enriched in genes targeted by FRMD6-AS2. Consistent with this finding, functional studies verified that FRMD6-AS2 can activate the Hippo signaling pathway by upregulating FRMD6 expression by promoting chromatin loop formation in the promoter region of FRMD6, thereby inhibiting the growth, migration and invasion of UCEC cells. As an upstream regulator of the conserved Hippo signaling pathway, FRMD6 has been reported to play a tumor-suppressive role in breast cancer and glioblastoma. ${ }^{130,131}$

\section{Other Cancers}

Multiple myeloma (MM) is a malignant proliferative disease of plasma cells and is usually confined to the bone marrow. ${ }^{132}$ Sun et $\mathrm{al}^{133}$ found that the IncRNA MALAT1 is upregulated in MM and is negatively associated with miR-181a-5p. Moreover, this group demonstrated that in the context of MALAT1 interference, the proliferative and adhesive abilities of myeloma cells were inhibited, whereas apoptosis was promoted; miR-181a-5p overexpression exhibited similar effects on myeloma cells. Mechanistic investigation revealed that MALAT1 can act as a ceRNA to sponge miR-181a-5p, while interference with MALAT1 expression can upregulate miR-181a-5p to increase the expression of LATS1 and phosphorylation of YAP, thereby suppressing malignant behaviors of myeloma cells via Hippo pathway activation. Osteosarcoma is the most frequently diagnosed bone tumor in adolescents. ${ }^{134} \mathrm{Su}$ et $\mathrm{al}^{57}$ observed a high level of the IncRNA MIR100HG in osteosarcoma tissues and cell lines and found that high MIR100HG expression is notably associated with poor prognosis in patients with osteosarcoma. MIR100HG knockdown leads to suppressed cell proliferation, cell cycle arrest, and enhanced apoptosis, but these effects can be partially abrogated by knockdown of either LATS1 or LATS2, implying that LATS1/2 are the underlying targets of MIR100HG. Mechanistically, Su et al confirmed that MIR100HG is localized in the nucleus and can epigenetically silence LATS $1 / 2$ by recruiting EZH2, a well-known histone methylation regulator, to the LATS1/2 promoter region, resulting in inactivation of the Hippo pathway. Cutaneous squamous cell carcinoma (CSCC), which is derived from keratinocytes, is the second most common cause of nonmelanoma skin cancer, and IncRNAs play an important role in its 
development and progression. ${ }^{135}$ By analyzing data from the TCGA database, Chen et $\mathrm{al}^{58}$ found that upregulation of LINC01048 is closely related to a worse survival outcome in CSCC than low expression of LINC01048. The results of in vivo and in vitro experiments indicated that knockdown of LINC01048 negatively regulates the proliferation of CSCC cells but promotes their apoptosis, suggesting the carcinogenic role of LINC01048 in CSCC. Furthermore, mechanistic experiments showed that LINC01048 interacts with the TAF15 protein, which has been identified as a transcriptional activator, ${ }^{136}$ and upregulates its expression; moreover, LINC01048 increases the binding of TAF15 to the YAP1 promoter, thus activating YAP1 transcription, in CSCC cells. In conclusion, LINC01048 may have prognostic or therapeutic value in CSCC.

\section{Clinical Application of LncRNAs in Hippo Pathway-Related Cancers Diagnosis and Prognosis}

The expression of lncRNAs is highly tissue specific; ${ }^{137}$ therefore, there has been great interest in the utilization of lncRNAs as potential biomarkers for early detection, diagnosis and prognosis. According to the studies presented in this review, a group of lncRNAs have been identified as dysregulated in Hippo pathway-related cancers. Some of the Hippo-related lncRNAs are significantly correlated with clinicopathological features and clinical prognoses in cancers. For example, in HCC patients, the expression of UCA1 is significantly upregulated and shows a positive association with a large tumor size, an advanced TNM stage and a poor prognosis. ${ }^{102}$ In contrast, a low level of lincRNA-p21 is closely related to a deep invasion depth, distant metastasis and an advanced TNM stage in gastric cancer. ${ }^{93}$ As the key downstream effectors of the Hippo pathway, YAP/TAZ have been found to be upregulated in multiple cancers, such as lung cancer and breast cancer, and are correlated with a poor prognosis. ${ }^{36,138}$ For instance, YAP/TAZ are highly expressed in most NSCLC specimens and associated with lymph node metastasis and short OS. ${ }^{139,140}$ These findings suggest that YAP/TAZ would be novel prognostic biomarkers.

\section{Treatment}

Many of the lncRNAs presented in this review have been reported to participate in cancer development and drug resistance by modulating the activity of the Hippo pathway, making them potential therapeutic targets. Research focused on targeting lncRNAs as cancer treatment is underway. In fact, the direct or indirect silencing of IncRNA expression is the most common strategy. Advancements in biological agents targeting lncRNAs, such as antisense oligonucleotides (ASOs) and small interfering RNAs (siRNAs), have indicated the feasibility of lncRNAs as a therapeutic target. $^{141-143}$

Numerous studies have shown that the Hippo signaling pathway not only regulates the growth of tumor cells but is also closely related to the resistance of tumor cells to chemotherapy drugs. ${ }^{75,84}$ Hence, the core components of the Hippo pathway are considered potential therapeutic targets for cancer. Given that the transcriptional activity of YAP/TAZ is mediated by TEADs, blocking the formation of the YAP/TAZ-TEAD complex may provide a new treatment strategy for human cancers. Recently, Verteporfin ( Vp) was identified as an inhibitor of YAP/ TAZ-TEAD function. Yu et al ${ }^{144}$ reported that Verteporfin exhibits an antitumorigenic effect in vitro. This drug can selectively kill uveal melanoma cells with elevated YAP activity. It may also provide another way to limit YAP/ TAZ function by modifying the upstream regulatory signals of the Hippo pathway, such as GPCR and F-actin. ${ }^{39,145}$ However, because these factors are not pathway specific and have corresponding physiological functions, the clinical feasibility of this method still needs further exploration.

\section{Discussion}

Cancer is a common disease that seriously threatens human health worldwide. The Hippo signaling pathway has been determined to play a crucial role in tumorigenesis and development in a wide range of cancers, such as thyroid, breast, and gastric cancers. Numerous studies have reported that IncRNAs can modulate the Hippo signaling pathway in cancer. In this review, we described the core signaling cascade of the Hippo pathway and highlighted the important role of lncRNAs in the regulation of this pathway in cancer.

As mentioned above, accumulating evidence indicates that the Hippo signaling pathway plays an important role in the development and progression of human cancers. In mammals, the upstream kinases of the Hippo pathway consist of the tumor suppressors MST1/2 and LATS1/2 and their adaptor proteins SAV1 and MOB1, while the 
downstream effectors consist of the oncogenes YAP/ TAZ. ${ }^{24-26}$ Similar to other central pathways, the conserved Hippo pathway can respond to diverse extracellular and intracellular signals to regulate the balance between cell proliferation and apoptosis to control tissue homeostasis. However, deregulation of this pathway destroys the balance and leads to an overgrowth phenotype and tumorigenesis. ${ }^{146,147}$ According to this review, the lncRNA-regulated Hippo pathway can act as both a suppressor and promoter of tumor progression. Therefore, a better understanding of the complex mechanisms underlying the effect of lncRNAs on the Hippo pathway is necessary for their further clinical applications.

As a group of noncoding RNA transcripts, lncRNAs have been confirmed to be functional elements that are involved in diverse biological processes in human malignancies, such as cell survival, carcinogenesis, tumor invasion, metastasis and angiogenesis. ${ }^{148}$ Studies have reported that IncRNAs are involved in the regulation of multiple key cancer-related pathways, such as the Notch, PI3K-Akt-mTOR, and $\beta$-catenin/Wnt pathways. ${ }^{149-151}$ In this review, we summarized 32 Hippo pathwayassociated lncRNAs in different cancers, 21 of which are upregulated and 11 of which are downregulated (Table 1). Similar to regulating other cancer-related pathways, IncRNAs can also regulate the activity of the Hippo pathway at the epigenetic, transcriptional, and posttranscriptional levels by interacting with DNA molecules, RNA molecules or proteins depending on their subcellular localization. Mechanistically, in the nucleus, lncRNAs participate in the transcription of the core Hippo kinases or directly bind to them to control their subcellular localization. ${ }^{55,57}$ In the cytoplasm, lncRNAs can function as decoys to compete for binding sites on miRNAs or interact with proteins, including Hippo pathway components and their regulatory proteins, to affect their stability and activity. ${ }^{62,63}$ Compared with other signaling pathways, a certain lncRNA may modulate the Hippo pathway in a different manner. For example, Gong et $\mathrm{al}^{152}$ found that HOTAIR was upregulated in HCC cells. HOTAIR targets the PI3K-Akt-mTOR pathway by acting as a ceRNA to sponge miR-217-5p, thereby promoting the development of HCC. However, in the Hippo pathway, HOTAIR can directly bind to the adaptor protein SAV1, leading to the inactivation of this pathway and promoting the malignant behavior of tumor cells. $^{127}$ Additionally, due to the tissue specificity of lncRNAs, the regulatory mechanism of dysregulated
lncRNAs in the Hippo pathway in different cancers also differs. As mentioned in our review, UCA1 is upregulated in both thyroid cancer and pancreatic cancer. This lncRNA inhibits the Hippo pathway by sponging miR$15 \mathrm{a}$ in thyroid cancer but promotes the activity of YAP by forming a shielding complex with MOB1, LATS1 and YAP in pancreatic cancer. ${ }^{70,108}$

From a clinical perspective, several studies have noted that molecules involved in the lncRNA-Hippo regulatory axis (eg, the lncRNA GAS5/miR-181c-5p/YAP axis in pancreatic cancer ${ }^{110}$ ) might be candidate therapeutic and prognostic biomarkers. However, it should be noted that there are still many limitations. First, as a prognostic biomarker, it is necessary to determine whether the expression pattern of an lncRNA or YAP is sufficiently stable It is also essential to establish a standard analytical protocol that includes sample extraction, detection methods and standard values. Second, in most cases, lncRNAs may not be the only cause of a dysregulated Hippo signaling pathway. In addition, there is crosstalk between the Hippo pathway and other signaling pathways. How to selectively target the Hippo pathway and ensure its physiological functions makes the clinical application of this therapeutic strategy highly challenging. Therefore, further studies are needed to test whether these molecules can be applied clinically for cancer therapy.

However, we still know little about the regulation of the Hippo pathway by $\operatorname{lncRNAs}$, and additional lncRNAs in the regulatory network of the Hippo signaling pathway remain to be discovered. Studies have indicated that lncRNAs do not regulate Hippo pathway activity through a single molecular mechanism, some of which have been described above. It is noted that the correlation between IncRNAs and the Hippo pathway tend to show cancer type specificity and spatiotemporal differences, and crosstalk with other pathways. Further investigations into the novel molecular signals regulating the Hippo pathway will be of paramount importance for understanding not only this pathway but also carcinogenesis.

In conclusion, we highlighted that lncRNAs are part of the Hippo signaling pathway regulatory network in cancer and summarized the complex underlying mechanisms, providing novel insight into carcinogenesis. In addition, these observations indicate that targeting these lncRNAs or Hippo pathway components is a new strategy for detecting and treating cancer. 
Table I LncRNA-Mediated Regulation of the Hippo Pathway in Cancer

\begin{tabular}{|c|c|c|c|c|c|c|c|c|}
\hline Cancer & & LncRNAs & Expression & Target & Mechanisms & Functions & Clinical Value & Reference \\
\hline \multirow{6}{*}{$\begin{array}{l}\text { Head and } \\
\text { neck } \\
\text { cancer }\end{array}$} & \multirow[t]{4}{*}{ Thyroid cancer } & MIR22HG & Down & - & - & - & Prognosis & [68] \\
\hline & & $\begin{array}{l}\text { TNRC6C- } \\
\text { ASI }\end{array}$ & Up & STK4 & $\begin{array}{l}\text { TNRC6C-ASI } \uparrow- \\
\text { STK4 } \downarrow\end{array}$ & $\begin{array}{l}\text { Promote } \\
\text { proliferation, } \\
\text { inhibit autophagy } \\
\text { and apoptosis }\end{array}$ & Therapy & [55] \\
\hline & & SNHGI5 & Up & YAPI & $\begin{array}{l}\text { SNHGI5个-miR } \\
-200 a-3 p \downarrow-Y A P I \uparrow\end{array}$ & $\begin{array}{l}\text { Promote cell } \\
\text { growth and } \\
\text { migration }\end{array}$ & Therapy & [59] \\
\hline & & UCAI & Up & - & $\begin{array}{l}\text { UCAI } \uparrow \text {-miR-I5a } \downarrow \text { - } \\
\text { Hippo inactivated }\end{array}$ & $\begin{array}{l}\text { Promote cell } \\
\text { proliferation and } \\
\text { EMT, suppress } \\
\text { cell apoptosis }\end{array}$ & Therapy & [70] \\
\hline & OscC & LEFI-ASI & Up & LATSI & $\begin{array}{l}\text { LEFI-ASI } \uparrow \text {-abolish } \\
\text { the binding of } \\
\text { LATSI to MOB }\end{array}$ & $\begin{array}{l}\text { Promote cell } \\
\text { survival, } \\
\text { proliferation and } \\
\text { migration, inhibit } \\
\text { cell apoptosis }\end{array}$ & $\begin{array}{l}\text { Prognosis, } \\
\text { therapy }\end{array}$ & [62] \\
\hline & NPC & MRVII-ASI & $\begin{array}{l}\text { Down in the } \\
\text { paclitaxel- } \\
\text { resistant } \\
\text { strains }\end{array}$ & TAZ & $\begin{array}{l}\text { MRVII-ASI } \downarrow-\mathrm{miR} \\
-5 \mid 3 \mathrm{a}-5 \mathrm{p} / \mathrm{miR}-27 \mathrm{~b}- \\
3 \mathrm{P} \uparrow-A T F 3 \downarrow- \\
\text { RASSFI } \downarrow-T A Z \uparrow\end{array}$ & $\begin{array}{l}\text { Increase NPC } \\
\text { paclitaxel } \\
\text { sensitivity }\end{array}$ & Therapy & [75] \\
\hline \multirow[t]{5}{*}{$\begin{array}{l}\text { Thoracic } \\
\text { cancer }\end{array}$} & Lung cancer & NSCLCATI & Up & - & $\begin{array}{l}\text { NSCLCATI } \uparrow- \\
\text { CDHI } \downarrow\end{array}$ & $\begin{array}{l}\text { Facilitate cell } \\
\text { proliferation, } \\
\text { migration and } \\
\text { invasion, inhibit } \\
\text { apoptosis }\end{array}$ & Therapy & [78] \\
\hline & \multirow[t]{4}{*}{ Breast cancer } & CYTOR & $\begin{array}{l}\text { Up in the } \\
\text { tamoxifen- } \\
\text { resistant cell } \\
\text { lines }\end{array}$ & TAZ & $\begin{array}{l}\text { CYTOR } \uparrow- \\
\text { miR- } 125 \mathrm{a}-5 \mathrm{p} \downarrow-\mathrm{SRF} \uparrow \\
-\mathrm{TAZ} \uparrow\end{array}$ & $\begin{array}{l}\text { Promote } \\
\text { tamoxifen } \\
\text { resistance }\end{array}$ & Therapy & [84] \\
\hline & & ZFHX4-ASI & Up & $\begin{array}{l}\text { YAP/ } \\
\text { TAZ }\end{array}$ & $\begin{array}{l}\text { ZFHX4-ASI } \uparrow- \\
\text { FAT4 } \downarrow-Y A P / T A Z \uparrow\end{array}$ & $\begin{array}{l}\text { Promote } \\
\text { proliferation, } \\
\text { invasion and } \\
\text { migration, inhibit } \\
\text { apoptosis }\end{array}$ & Therapy & [86] \\
\hline & & LINC00673 & Up & $\begin{array}{l}\text { MST/ } \\
\text { SAV }\end{array}$ & $\begin{array}{l}\text { LINC00673个-miR } \\
-5 \text { I5-5p } \downarrow-M A R K 4 \uparrow- \\
\text { attenuate the } \\
\text { binding of MST/SAV } \\
\text { to LATS }\end{array}$ & $\begin{array}{l}\text { Promote cell } \\
\text { proliferation }\end{array}$ & Therapy & [88] \\
\hline & & Linc-OIP5 & Up & YAPI & Linc-OIP5 $\uparrow-Y A P I \downarrow$ & $\begin{array}{l}\text { Promote } \\
\text { proliferation, } \\
\text { migration and } \\
\text { invasion, inhibit } \\
\text { apoptosis }\end{array}$ & Therapy & [89] \\
\hline
\end{tabular}


Table I (Continued).

\begin{tabular}{|c|c|c|c|c|c|c|c|c|}
\hline Cancer & & LncRNAs & Expression & Target & Mechanisms & Functions & Clinical Value & Reference \\
\hline & & MAYA & Up & MSTI & 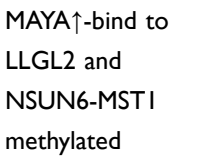 & $\begin{array}{l}\text { Mediate bone } \\
\text { metastasis }\end{array}$ & Therapy & [91] \\
\hline \multirow[t]{10}{*}{$\begin{array}{l}\text { Abdominal } \\
\text { cancer }\end{array}$} & \multirow[t]{4}{*}{$\begin{array}{l}\text { Gastric } \\
\text { carcinoma }\end{array}$} & $\begin{array}{l}\text { AP000695.6, } \\
\text { RPII- } \\
\text { I08MI } 2.3\end{array}$ & Down & - & - & - & Prognosis & [92] \\
\hline & & $\begin{array}{l}\text { CYP4A22- } \\
\text { ASI }\end{array}$ & Up & - & - & - & Prognosis & [92] \\
\hline & & LINC00662 & Up & YAPI & $\begin{array}{l}\text { LINC00662 } \uparrow-m i R \\
-497-5 p \downarrow-Y A P I \uparrow\end{array}$ & $\begin{array}{l}\text { Increase } \\
\text { proliferation, } \\
\text { decrease the } \\
\text { sensitivity to } \\
\text { 5-FU }\end{array}$ & $\begin{array}{l}\text { Prognosis, } \\
\text { therapy }\end{array}$ & [60] \\
\hline & & lincRNA-p2I & Down & YAP & $\begin{array}{l}\text { lincRNA-p2I } \downarrow- \\
\text { YAP } \uparrow\end{array}$ & $\begin{array}{l}\text { Inhibit cell } \\
\text { proliferation and } \\
\text { EMT process }\end{array}$ & $\begin{array}{l}\text { Prognosis, } \\
\text { therapy, invasion } \\
\text { depth grade, } \\
\text { metastasis, TNM } \\
\text { stage }\end{array}$ & [93] \\
\hline & $\begin{array}{l}\text { Colorectal } \\
\text { cancer }\end{array}$ & $\begin{array}{l}\text { B4GALTI - } \\
\text { ASI }\end{array}$ & $U_{p}$ & YAP & $\begin{array}{l}\text { B4GALTI-ASI } \uparrow- \\
\text { YAP nuclear } \\
\text { translocation } \uparrow\end{array}$ & $\begin{array}{l}\text { Promote cell } \\
\text { stemness, } \\
\text { migration, } \\
\text { invasion, and } \\
\text { EMT process }\end{array}$ & Therapy & [61] \\
\hline & \multirow[t]{4}{*}{$\begin{array}{l}\text { Hepatocellular } \\
\text { carcinoma }\end{array}$} & PVTI & $U_{p}$ & - & - & - & $\begin{array}{l}\text { Diagnosis, } \\
\text { gender, race, } \\
\text { vascular invasion } \\
\text { and pathological } \\
\text { grade }\end{array}$ & [99] \\
\hline & & UCAI & $U_{p}$ & - & - & $\begin{array}{l}\text { Promote cell } \\
\text { proliferation, } \\
\text { inhibit apoptosis }\end{array}$ & $\begin{array}{l}\text { Prognosis, tumor } \\
\text { size, TNM stages }\end{array}$ & [102] \\
\hline & & uc. 134 & Down & LATSI & $\begin{array}{l}\text { uc. } 134 \downarrow-C U L 4 A \\
\text { nuclear export } \uparrow- \\
\text { LATSI } \downarrow\end{array}$ & $\begin{array}{l}\text { Inhibit cell } \\
\text { proliferation, } \\
\text { invasion, and } \\
\text { metastasis }\end{array}$ & $\begin{array}{l}\text { Prognosis, } \\
\text { therapy }\end{array}$ & {$[103]$} \\
\hline & & LINCO 1314 & Down & MTSI & $\begin{array}{l}\text { LINCOI3I4 } \downarrow- \\
\text { MTSI } \downarrow\end{array}$ & $\begin{array}{l}\text { Reduce cell } \\
\text { proliferation, } \\
\text { migration, and } \\
\text { invasion }\end{array}$ & $\begin{array}{l}\text { Prognosis, } \\
\text { therapy }\end{array}$ & [106] \\
\hline & $\begin{array}{l}\text { Pancreatic } \\
\text { cancer }\end{array}$ & UCAI & $U_{p}$ & YAP & 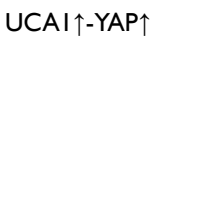 & $\begin{array}{l}\text { Promote } \\
\text { migration and } \\
\text { invasion }\end{array}$ & $\begin{array}{l}\text { Prognosis, } \\
\text { therapy, } \\
\text { clinicopathologic- } \\
\text { al features, } \\
\text { clinical stage }\end{array}$ & {$[108]$} \\
\hline
\end{tabular}

(Continued) 
Table I (Continued).

\begin{tabular}{|c|c|c|c|c|c|c|c|c|}
\hline Cancer & & LncRNAs & Expression & Target & Mechanisms & Functions & Clinical Value & Reference \\
\hline & & MALATI & $U_{p}$ & $\begin{array}{l}\text { LATSI/ } \\
\text { YAPI }\end{array}$ & 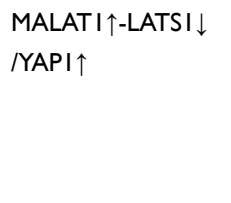 & $\begin{array}{l}\text { Promote } \\
\text { proliferation, } \\
\text { migration and } \\
\text { invasion, inhibit } \\
\text { apoptosis }\end{array}$ & Therapy & [109] \\
\hline & & GAS5 & $\begin{array}{l}\text { Down in the } \\
\text { drug- } \\
\text { resistant cell } \\
\text { lines }\end{array}$ & MSTI & $\begin{array}{l}\text { GAS5 } \downarrow-\text { miR-I8Ic- } \\
5 \mathrm{P} \uparrow-M S T I \downarrow\end{array}$ & $\begin{array}{l}\text { Antagonize the } \\
\text { development of } \\
\text { multidrug } \\
\text { resistance, inhibit } \\
\text { cell viability }\end{array}$ & Therapy & {$[110]$} \\
\hline \multirow[t]{4}{*}{$\begin{array}{l}\text { Central } \\
\text { nervous } \\
\text { system } \\
\text { tumor }\end{array}$} & Glioblastoma & BDNF-AS & Down & YAP & $\begin{array}{l}\text { BDNF-AS } \downarrow-R A X 2 \uparrow- \\
\text { DLG5 } \downarrow-Y A P \\
\text { phosphorylated } \downarrow\end{array}$ & $\begin{array}{l}\text { Inhibit } \\
\text { proliferation, } \\
\text { migration, and } \\
\text { invasion, increase } \\
\text { apoptosis }\end{array}$ & Therapy & [114] \\
\hline & \multirow[t]{2}{*}{ Glioma } & KCNQIOTI & Up & YAP & $\begin{array}{l}\text { KCNQIOTI } \uparrow-m i R \\
-370 \downarrow-C C N E 2 \uparrow- \\
\text { YAP } \\
\text { phosphorylated } \downarrow\end{array}$ & $\begin{array}{l}\text { Promote cell } \\
\text { proliferation, } \\
\text { migration and } \\
\text { invasion, inhibit } \\
\text { apoptosis }\end{array}$ & Therapy & [117] \\
\hline & & LINC00473 & $U_{p}$ & YAPI & $\begin{array}{l}\text { LINC00473个- } \\
\text { miR-I95-5p } \downarrow- \\
\text { YAPI } \uparrow\end{array}$ & $\begin{array}{l}\text { induce cell } \\
\text { proliferation, } \\
\text { invasion and } \\
\text { migration, reduce } \\
\text { apoptosis }\end{array}$ & $\begin{array}{l}\text { Prognosis, } \\
\text { therapy }\end{array}$ & [119] \\
\hline & Medulloblastoma & $N k \times 2-2 a s$ & Down & $\begin{array}{l}\text { LATSI/ } \\
2\end{array}$ & $\begin{array}{l}\text { Nkx2-2as } \downarrow-\mathrm{miR} \\
-103 \mathrm{a} / \mathrm{I07}, \mathrm{miR}- \\
548 \mathrm{~m} \uparrow-\mathrm{LATSI} / 2 \downarrow\end{array}$ & $\begin{array}{l}\text { impair colony } \\
\text { formation and } \\
\text { invasion, induce } \\
\text { cell apoptosis }\end{array}$ & Therapy & {$[121]$} \\
\hline \multirow[t]{4}{*}{$\begin{array}{l}\text { Urogenital } \\
\text { cancer }\end{array}$} & \multirow[t]{2}{*}{$\mathrm{RCC}$} & TUGI & Up & YAP & 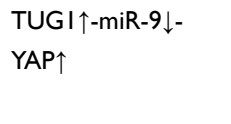 & $\begin{array}{l}\text { promote cell } \\
\text { proliferation and } \\
\text { migration }\end{array}$ & Therapy & [126] \\
\hline & & HOTAIR & $U_{p}$ & SAVI & $\begin{array}{l}\text { HOTAIR } \uparrow \text {-SAVI } \\
\text { activity } \downarrow\end{array}$ & $\begin{array}{l}\text { promote cell } \\
\text { proliferation, } \\
\text { migration, and } \\
\text { tumor growth }\end{array}$ & $\begin{array}{l}\text { Prognosis, } \\
\text { therapy }\end{array}$ & [127] \\
\hline & EOC & UCAI & $U_{p}$ & YAP & $\begin{array}{l}\text { UCAI } \uparrow \text {-the } \\
\text { interaction between } \\
\text { AMOT and YAP } \uparrow \text { - } \\
\text { YAP activity } \uparrow\end{array}$ & $\begin{array}{l}\text { promote tumor } \\
\text { growth }\end{array}$ & Therapy & [63] \\
\hline & UCEC & FRMD6-AS2 & Down & - & $\begin{array}{l}\text { FRMD6-AS2 } \downarrow- \\
\text { FRMD6 } \downarrow-H i p p o \\
\text { inactivated }\end{array}$ & $\begin{array}{l}\text { inhibit cell } \\
\text { growth, migration } \\
\text { and invasion }\end{array}$ & Therapy & [56] \\
\hline Others & $\begin{array}{l}\text { Multiple } \\
\text { myeloma }\end{array}$ & MALATI & Up & LASTI & $\begin{array}{l}\text { MALATI } \uparrow-m i R \\
-\mid 8 \mathrm{Ia}-5 \mathrm{p} \downarrow-L A S T I \downarrow\end{array}$ & $\begin{array}{l}\text { promote } \\
\text { proliferation and } \\
\text { adhesion, inhibit } \\
\text { apoptosis }\end{array}$ & Therapy & [133] \\
\hline
\end{tabular}

(Continued) 
Table I (Continued).

\begin{tabular}{|l|l|l|l|l|l|l|l|l|}
\hline Cancer & & LncRNAs & Expression & Target & Mechanisms & Functions & Clinical Value & Reference \\
\hline \multirow{2}{*}{} & Osteosarcoma & MIRI00HG & UP & $\begin{array}{l}\text { LATSI/ } \\
2\end{array}$ & $\begin{array}{l}\text { MIRI00HG } \uparrow- \\
\text { recruit EZH2- } \\
\text { LATSI/2 } \downarrow\end{array}$ & $\begin{array}{l}\text { induce cell } \\
\text { proliferation, cell } \\
\text { cycle arrest, } \\
\text { inhibit apoptosis }\end{array}$ & $\begin{array}{l}\text { Prognosis, } \\
\text { therapy }\end{array}$ & {$[57]$} \\
\cline { 2 - 7 } & CSCC & LINC0I048 & UP & YAPI & $\begin{array}{l}\text { LINC0I048 } \uparrow- \\
\text { recruit TAFI5- } \\
\text { YAPI } \uparrow\end{array}$ & $\begin{array}{l}\text { promote cell } \\
\text { proliferation, } \\
\text { inhibit apoptosis }\end{array}$ & $\begin{array}{l}\text { Prognosis, } \\
\text { therapy }\end{array}$ & {$[58]$} \\
\hline
\end{tabular}

\section{Author Contributions}

All authors made a significant contribution to the work reported, whether that is in the conception, study design, execution, acquisition of data, analysis and interpretation, or in all these areas; took part in drafting, revising or critically reviewing the article; gave final approval of the version to be published; have agreed on the journal to which the article has been submitted; and agree to be accountable for all aspects of the work.

\section{Funding}

This work was supported by grants from the National Natural Science Foundation of China (No. 81672307, 81871871), Key Research and Development plan (Social development) of science and technology department of Jiangsu Province (No.BE2019760) and the Medical Innovation Team Foundation of the Jiangsu Provincial Enhancement Health Project (No. CXTDA2017021).

\section{Disclosure}

The authors declare that they have no competing interests.

\section{References}

1. Bray F, Ferlay J, Soerjomataram I, Siegel RL, Torre LA, Jemal A. Global cancer statistics 2018: GLOBOCAN estimates of incidence and mortality worldwide for 36 cancers in 185 countries. CA Cancer J Clin. 2018;68:394-424. doi:10.3322/caac.21492

2. Hanahan D, Weinberg RA. Hallmarks of cancer: the next generation. Cell. 2011;144:646-674. doi:10.1016/j.cell.2011.02.013

3. Vogelstein B, Papadopoulos N, Velculescu VE, Zhou S, Diaz LA Jr, Kinzler KW. Cancer genome landscapes. Science. 2013;339:15 46-1558. doi:10.1126/science. 1235122

4. Sanchez-Vega F, Mina M, Armenia J, et al. Oncogenic signaling pathways in the cancer genome atlas. Cell. 2018;173:321-+.

5. Pottier C, Fresnais M, Gilon M, Jerusalem G, Longuespee R, Sounni NE. Tyrosine kinase inhibitors in cancer: breakthrough and challenges of targeted therapy. Cancers. 2020;12.

6. Rw J, Zilian O, Woods DF, Noll M, Bryant PJ. The Drosophila tumor suppressor gene warts encodes a homolog of human myotonic dystrophy kinase and is required for the control of cell shape and proliferation. Genes Dev. 1995;9:534-546. doi:10.1101/gad.9.5.534
7. Xu T, Wang W, Zhang S, Stewart RA, Yu W. Identifying tumor suppressors in genetic mosaics: the Drosophila lats gene encodes a putative protein kinase. Development. 1995;121:1053-1063.

8. Halder G, Johnson RL. Hippo signaling: growth control and beyond. Development. 2011;138:9-22. doi:10.1242/dev.045500

9. Ramos A, Camargo FD. The Hippo signaling pathway and stem cell biology. Trends Cell Biol. 2012;22:339-346. doi:10.1016/j. tcb.2012.04.006

10. Zhao B, Tumaneng K, Guan KL. The Hippo pathway in organ size control, tissue regeneration and stem cell self-renewal. Nat Cell Biol. 2011;13:877-883. doi:10.1038/ncb2303

11. Moroishi T, Hayashi T, Pan WW, et al. The Hippo pathway kinases LATS1/2 suppress cancer immunity. Cell. 2016;16 7:1525-+. doi:10.1016/j.cell.2016.11.005

12. Zheng YG, Pan DJ. The Hippo Signaling pathway in development and disease. Dev Cell. 2019;50:264-282. doi:10.1016/j. devcel.2019.06.003

13. Clark MB, Mattick JS. Long noncoding RNAs in cell biology. Semin Cell Dev Biol. 2011;22:366-376. doi:10.1016/j.semcdb.2011.01.001

14. Mattick JS, Amaral PP, Dinger ME, Mercer TR, Mehler MF. RNA regulation of epigenetic processes. Bioessays. 2009;31 (1):51-59. doi:10.1002/bies.080099

15. Orom UA, Derrien T, Beringer M, et al. Long noncoding RNAs with enhancer-like function in human cells. Cell. 2010;14 3:46-58. doi:10.1016/j.cell.2010.09.001

16. Rashid F, Shah A, Shan G. Long non-coding RNAs in the cytoplasm. Genomics Proteomics Bioinformatics. 2016;14:73-80. doi:10.1016/j.gpb.2016.03.005

17. Huarte M. The emerging role of IncRNAs in cancer. Nat Med. 2015;21:1253-1261. doi:10.1038/nm.3981

18. Li CH, Chen YC. Small and long non-coding RNAs: novel targets in perspective Cancer Therapy. Curr Genomics. 2015;16: 319-326. doi:10.2174/1389202916666150707155851

19. Xu T, Jiang L, Wang $\mathrm{Z}$. The progression of HMGB1-induced autophagy in cancer biology. Onco Targets Ther. 2019;12:36 5-377. doi:10.2147/OTT.S185876

20. Zhang L, Kang W, Lu X, Ma S, Dong L, Zou B. LncRNA CASC11 promoted gastric cancer cell proliferation, migration and invasion in vitro by regulating cell cycle pathway. Cell Cycle. 2018;17:1886-1900. doi:10.1080/15384101.2018.1502574

21. Zhang Y, Wu J, Jing H, Huang G, Sun ZL, Xu SM. Long noncoding RNA MEG3 inhibits breast cancer growth via upregulating endoplasmic reticulum stress and activating NF-kappa B and p53. J Cell Biochem. 2019;120:6789-6797. doi:10.1002/jcb.27982

22. Dai QQ, Zhang TQ, Li C. LncRNA MALAT I regulates the cell proliferation and cisplatin resistance in gastric cancer via PI3K/ AKT pathway. Cancer Manag Res. 2020;12:1929-1939. doi:10. 2147/CMAR.S243796

23. Tu C, Yang K, Wan L, et al. The crosstalk between lncRNAs and the Hippo signalling pathway in cancer progression. Cell Prolif. 2020;53:e12887. doi:10.1111/cpr.12887 
24. Chan EH, Nousiainen M, Chalamalasetty RB, Schafer A, Nigg EA, Sillje HHW. The Ste20-like kinase Mst2 activates the human large tumor suppressor kinase Lats1. Oncogene. 2005;24:2076-2086. doi:10.1038/sj.onc.1208445

25. Praskova M, Xia F, Avruch J. MOBKL1A/MOBKL1B phosphorylation by MST1 and MST2 inhibits cell proliferation. Current Biol. 2008;18:311-321. doi:10.1016/j.cub.2008.02.006

26. Callus BA, Verhagen AM, Vaux DL. Association of mammalian sterile twenty kinases, Mst1 and Mst2, with hSalvador via C-terminal coiled-coil domains, leads to its stabilization and phosphorylation. FEBS J. 2006;273(18):4264-4276. doi:10.11 11/j.1742-4658.2006.05427.x

27. Zhao B, Wei X, Li W, et al. Inactivation of YAP oncoprotein by the Hippo pathway is involved in cell contact inhibition and tissue growth control. Genes Dev. 2007;21:2747-2761. doi:10.1101/gad.1602907

28. Lei QY, Zhang H, Zhao B, et al. TAZ promotes cell proliferation and epithelial-mesenchymal transition and is inhibited by the hippo pathway. Mol Cell Biol. 2008;28:2426-2436. doi:10.1128/ MCB.01874-07

29. Zhao B, Ye X, Yu JD, et al. TEAD mediates YAP-dependent gene induction and growth control. Genes Dev. 2008;22(14):19 62-1971. doi:10.1101/gad.1664408

30. Dong JX, Feldmann G, Huang JB, et al. Elucidation of a universal size-control mechanism in Drosophila and mammals. Cell. 2007;130:1120-1133. doi:10.1016/j.cell.2007.07.019

31. Piccolo S, Dupont S, Cordenonsi M. The biology of Yap/Taz: hippo signaling and beyond. Physiol Rev. 2014;94:1287-1312. doi:10.1152/physrev.00005.2014

32. Wang KN, Degerny C, Xu MH, Yang XJ. YAP, TAZ, and Yorkie: a conserved family of signal-responsive transcriptional coregulators in animal development and human disease. Biochem Cell Biol Biochimie Et Biologie Cellulaire. 2009;87:77-91. doi:10.11 39/O08-114

33. Yu FX, Zhao B, Guan KL. Hippo pathway in organ size control, tissue homeostasis, and cancer. Cell. 2015;163:811-828. doi:10.1016/j.cell.2015.10.044

34. Xiao H, Jiang N, Zhou BY, Liu Q, Du CY. TAZ regulates cell proliferation and epithelial-mesenchymal transition of human hepatocellular carcinoma. Cancer Sci. 2015;106:151-159. doi:10.1111/ cas. 12587

35. Rashidian J, Le Scolan E, Ji XD, et al. Ski regulates Hippo and TAZ signaling to suppress breast cancer progression. Sci Signal. 2015;8(363):8. doi:10.1126/scisignal.2005735

36. Wang LJ, Shi SJ, Guo ZY, et al. Overexpression of YAP and TAZ is an independent predictor of prognosis in colorectal cancer and related to the proliferation and metastasis of colon cancer cells. PLoS One. 2013;8.

37. Tamm C, Bower N, Anneren C. Regulation of mouse embryonic stem cell self-renewal by a Yes-YAP-TEAD2 signaling pathway downstream of LIF. J Cell Sci. 2011;124:1136-1144. doi:10.1242/ jcs.075796

38. Cottini F, Hideshima T, Xu C, et al. Rescue of Hippo coactivator YAP1 triggers DNA damage-induced apoptosis in hematological cancers. Nat Med. 2014;20:599-606. doi:10.1038/nm.3562

39. Yu FX, Zhao B, Panupinthu N, et al. Regulation of the Hippo-YAP pathway by G-protein-coupled receptor signaling. Cell. 2012;150:780-791. doi:10.1016/j.cell.2012.06.037

40. Genevet A, Tapon N. The Hippo pathway and apico-basal cell polarity. Biochem J. 2011;436:213-224. doi:10.1042/BJ20110217

41. Sopko R, McNeill H. The skinny on Fat: an enormous cadherin that regulates cell adhesion, tissue growth, and planar cell polarity. Curr Opin Cell Biol. 2009;21:717-723. doi:10.1016/j. ceb.2009.07.001

42. Schroeder MC, Halder G. Regulation of the Hippo pathway by cell architecture and mechanical signals. Semin Cell Dev Biol. 2012;23:803-811.
43. Mo JS, Meng ZP, Kim YC, et al. Cellular energy stress induces AMPK-mediated regulation of YAP and the Hippo pathway. Nat Cell Biol. 2015;17:500-+. doi:10.1038/ncb3111

44. Mo JS, Park HW, Guan KL. The Hippo signaling pathway in stem cell biology and cancer. EMBO Rep. 2014;15:642-656. doi:10. 15252/embr.201438638

45. Yin F, Yu JZ, Zheng YG, Chen Q, Zhang NL, Pan DJ. Spatial organization of hippo signaling at the plasma membrane mediated by the tumor suppressor Merlin/NF2. Cell. 2013;154:1342-1355. doi:10.1016/j.cell.2013.08.025

46. Yu JZ, Zheng YG, Dong JX, Klusza S, Deng WM, Pan DJ. Kibra functions as a tumor suppressor protein that regulates hippo signaling in conjunction with merlin and expanded. Dev Cell. 2010;18:288-299. doi:10.1016/j.devcel.2009.12.012

47. Kim NG, Koh E, Chen X, Gumbiner BM. E-cadherin mediates contact inhibition of proliferation through Hippo signaling-pathway components. Proc Natl Acad Sci U S A. 2011;108:11930-11935.

48. Zhao B, Li L, Lu Q, et al. Angiomotin is a novel Hippo pathway component that inhibits YAP oncoprotein. Genes Dev. 2011;25 (1):51-63. doi:10.1101/gad.2000111

49. Mao YP, Mulvaney J, Zakaria S, et al. Characterization of a Dchs1 mutant mouse reveals requirements for Dchs1-Fat4 signaling during mammalian development. Development. 2011;138 (5):947-957. doi:10.1242/dev.057166

50. Arash EH, Shiban A, Song SY, Attisano L. MARK4 inhibits Hippo signaling to promote proliferation and migration of breast cancer cells. EMBO Rep. 2017;106(3):420-436. doi:10.15252/embr.201642455

51. Praskova M, Khoklatchev A, Ortiz-Vega S, Avruch J. Regulation of the MST1 kinase by autophosphorylation, by the growth inhibitory proteins, RASSF1 and NORE1, and by Ras. Biochem $J$. 2004;381:453-462. doi:10.1042/BJ20040025

52. Zhan LX, Rosenberg A, Bergami KC, et al. Deregulation of scribble promotes mammary tumorigenesis and reveals a role for cell polarity in carcinoma. Cell. 2008;135:865-878. doi:10. 1016/j.cell.2008.09.045

53. Grzeschik NA, Parsons LM, Allott ML, Harvey KF, Richardson HE. Lgl, aPKC, and crumbs regulate the Salvador/ Warts/Hippo pathway through two distinct mechanisms. Current Biol. 2010;20:573-581. doi:10.1016/j.cub.2010.01.055

54. Angus L, Moleirinho S, Herron L, et al. Willin/FRMD6 expression activates the Hippo signaling pathway kinases in mammals and antagonizes oncogenic YAP. Oncogene. 2012;31:238-250.

55. Peng XZ, Ji CC, Tan LP, et al. Long non-coding RNA TNRC6C-AS1 promotes methylation of STK4 to inhibit thyroid carcinoma cell apoptosis and autophagy via Hippo signalling pathway. $J$ Cell $\mathrm{Mol}$ Med. 2020;24:304-316. doi:10.1111/jcmm.14728

56. Wang, J, Li, ZH, Wang, XL, Ding, Y, Li, N. The tumor suppressive effect of long non-coding RNA FRMD6-AS2 in uteri corpus endometrial carcinoma. Life Sci. 2020;(243)

57. Su XC, Teng JY, Jin GG, et al. ELK1-induced upregulation of long non-coding RNA MIR100HG predicts poor prognosis and promotes the progression of osteosarcoma by epigenetically silencing LATS1 and LATS2. Biomed Pharmacother. 2019;109: 788-797. doi:10.1016/j.biopha.2018.10.029

58. Chen LZ, Chen Q, Kuang SF, et al. USF1-induced upregulation of LINC01048 promotes cell proliferation and apoptosis in cutaneous squamous cell carcinoma by binding to TAF15 to transcriptionally activate YAP1. Cell Death Dis. 2019;10.

59. Wu DM, Wang S, Wen X, et al. LncRNA SNHG15 acts as a ceRNA to regulate YAP1-Hippo signaling pathway by sponging miR-200a-E3p in papillary thyroid carcinoma. Cell Death Dis. 2018;9(9). doi:10.1038/s41419-018-0975-1.

60. Liu Z, Yao YY, Huang SS, et al. LINC00662 promotes gastric cancer cell growth by modulating the Hippo-YAP1 pathway. Biochem Biophys Res Commun. 2018;505:843-849. doi:10.101 6/j.bbrc.2018.09.191 
61. Zhang Y, Fang ZX, Guo X, et al. lncRNA B4GALT1-AS1 promotes colon cancer cell stemness and migration by recruiting YAP to the nucleus and enhancing YAP transcriptional activity. J Cell Physiol. 2019;234:18524-18534. doi:10.1002/jcp.28489

62. Zhang CQ, Bao CC, Zhang XX, Lin XS, Pan D, Chen YZ. Knockdown of lncRNA LEF1-AS1 inhibited the progression of oral squamous cell carcinoma (OSCC) via Hippo signaling pathway. Cancer Biol Ther. 2019;20:1213-1222. doi:10.1080/ 15384047.2019.1599671

63. Lin XZ, Spindler TJ, Fonseca MAD, et al. Super-enhancerassociated LncRNA UCA1 interacts directly with AMOT to activate YAP target genes in epithelial ovarian cancer. iScience. 2019;17:242-+. doi:10.1016/j.isci.2019.06.025

64. Me C, Dg M. Thyroid Cancer. Lancet. 2016;388:2783-2795.

65. Kitahara CM, Sosa JA. The changing incidence of thyroid cancer. Nat Rev Endocrinol. 2016;12:646-653. doi:10.1038/nrendo.2016.110

66. Torre LA, Siegel RL, Ward EM, Jemal A. Global cancer incidence and mortality rates and trends-an update. Cancer Epidemiol Biomark Prev. 2016;25:16-27. doi:10.1158/1055-9965.EPI-15-0578

67. Ghafouri-Fard S, Mohammad-Rahimi H, Taheri M. The role of long non-coding RNAs in the pathogenesis of thyroid cancer. Exp Mol Pathol. 2020;112.

68. Qin L, Luo JZ, Tang XL, Han CG. Identification of long noncoding RNA MIR22HG as a novel biomarker in thyroid cancer. Pathol Oncol Res. 2019;25:703-710. doi:10.1007/s12253-0180521-6

69. Yang LX, Wu J, Guo ML, Zhang Y, Ma SG. Suppression of long non-coding RNA TNRC6C-AS1 protects against thyroid carcinoma through DNA demethylation of STK4 via the Hippo signalling pathway. Cell Prolif. 2019;52(52):e12564. doi:10.1111/ cpr.12564

70. Li DD, Hao S, Zhang J. Long non-coding RNA UCA1 exerts growth modulation by miR-15a in human thyroid cancer TPC-1 cells. Artif Cells, Nanomed Biotechnol. 2019;47:1815-1822. doi:10.1080/21691401.2019.1606007

71. Jyk C, Zhen G, Agrawal N. The role of tumor DNA as a diagnostic tool for head and neck squamous cell carcinoma. Semin Cancer Biol. 2019;55:1-7. doi:10.1016/j.semcancer.2018.07.008

72. Warnakulasuriya S. Global epidemiology of oral and oropharyngeal cancer. Oral Oncol. 2009;45:309-316. doi:10.1016/j. oraloncology.2008.06.002

73. Wang Y, Fang Z, Hong M, Yang D, Xie W. Long-noncoding RNAs (lncRNAs) in drug metabolism and disposition, implications in cancer chemo-resistance. Acta Pharm Sin B. 2020; 10:105-112. doi:10.1016/j.apsb.2019.09.011

74. Matsui M, Corey DR. Non-coding RNAs as drug targets. Nat Rev Drug Discov. 2017;16:167-179. doi:10.1038/nrd.2016.117

75. Zhu Y, He D, Bo H, et al. The MRVI1-AS1/ATF3 signaling loop sensitizes nasopharyngeal cancer cells to paclitaxel by regulating the Hippo-TAZ pathway. Oncogene. 2019;38:6065-6081. doi:10. 1038/s41388-019-0858-7

76. Rl S, Kd M, Jemal A, et al. Cancer Statistics, 2017. CA Cancer J Clin. 2017;67:7-30. doi:10.3322/caac.21387

77. Qiao F, Li N, Li W. Integrative bioinformatics analysis reveals potential long non-coding RNA biomarkers and analysis of function in non-smoking females with lung cancer. Med Sci Monit. 2018;24:5771-5778. doi:10.12659/MSM.908884

78. Zhao W, Zhang L-N, Wang X-L, Zhang J, Yu H-X. Long noncoding RNA NSCLCAT1 increases non-small cell lung cancer cell invasion and migration through the Hippo signaling pathway by interacting with CDH1. FASEB $j$. 2019;33:1151-1166. doi:10. 1096/fj.201800408R

79. Sn R, Ml K, Ja M, et al. CDH1 is essential for endometrial differentiation, gland development, and adult function in the mouse uterus. Biol Reprod. 2012;86(141):110-141. doi:10.1095/ biolreprod.112.098871
80. $\mathrm{Ng} \mathrm{K}$. E-cadherin mediates contact inhibition of proliferation through Hippo signaling-pathway components. Proc Natl Acad Sci U S A. 2011;108:11930-11935. doi:10.1073/pnas.1103345108

81. Mattiuzzi C, Lippi G. Current cancer epidemiology. J Epidemiol Glob Health. 2019;9:217-222. doi:10.2991/jegh.k.191008.001

82. $\mathrm{Ag} \mathrm{W}, \mathrm{Ep} \mathrm{W}$. Breast cancer treatment: a review. JAMA. 2019;321:288-300. doi:10.1001/jama.2018.19323

83. Rozeboom B, Dey N, De P. ER+ metastatic breast cancer: past, present, and a prescription for an apoptosis-targeted future. $\mathrm{Am}$ J Cancer Res. 2019;9:2821-2831.

84. Liu Y, Li M, Yu H, Piao H. IncRNA CYTOR promotes tamoxifen resistance in breast cancer cells via sponging miR125a5p. Int J Mol Med. 2020;45:497-509. doi:10.3892/ijmm.2019.4428

85. Liu CY, Chan SW, Guo F, Toloczko A, Cui L, Hong W. MRTF/ SRF dependent transcriptional regulation of TAZ in breast cancer cells. Oncotarget. 2016;7:13706-13716. doi:10.18632/oncotarget. 7333

86. Li SY, Wang H, Mai HF, et al. Down-regulated long non-coding RNA RNAZFHX4-AS1 suppresses invasion and migration of breast cancer cells via FAT4-dependent Hippo signaling pathway. Cancer Gene Ther. 2019;26:374-387. doi:10.1038/s414 17-018-0066-6

87. Qi C, Zhu YT, Hu LP, Zhu YJ. Identification of Fat4 as a candidate tumor suppressor gene in breast cancers. Int $J$ Cancer. 2009;124:793-798. doi:10.1002/ijc.23775

88. Qiao K, Ning SP, Wan L, et al. LINC00673 is activated by YY1 and promotes the proliferation of breast cancer cells via the miR-515-5p/MARK4/Hippo signaling pathway. $J$ Exp Clin Cancer Res. 2019;38(38). doi:10.1186/s13046-019-1421-7.

89. Zhu Q, Li YS, Dong XM, Yang Y, Wang HY, Guo SF. Linc-OIP5 loss regulates migration and invasion in MDA-MB-231 breast cancer cells by inhibiting YAP1/JAG1 signaling. Oncol Lett. 2020;19:103-112. doi:10.3892/ol.2019.11071

90. Kang YB, Siegel PM, Shu WP, et al. A multigenic program mediating breast cancer metastasis to bone. Cancer Cell. 2003;3:537-549. doi:10.1016/S1535-6108(03)00132-6

91. Li C, Wang S, Xing Z, et al. A ROR1-HER3-lncRNA signalling axis modulates the Hippo-YAP pathway to regulate bone metastasis. Nat Cell Biol. 2017;19(2):106-119. doi:10.1038/ncb3464

92. Cheng P. A prognostic 3-long noncoding RNA signature for patients with gastric cancer. J Cell Biochem. 2018;119:92 61-9269. doi:10.1002/jcb.27195

93. Chen Y, Wei GQ, Xia HW, Yu HF, Tang QL, Bi F. Down regulation of lincRNA-p21 contributes to gastric cancer development through Hippo-independent activation of YAP. Oncotarget. 2017;8:63813-63824. doi:10.18632/oncotarget.19130

94. Zhang H, Wang Z, Wu JZ, Ma R, Feng JF. Long noncoding RNAs predict the survival of patients with colorectal cancer as revealed by constructing an endogenous RNA network using bioinformation analysis. Cancer Med. 2019;8:863-873. doi:10.10 02/cam4.1813

95. Petrick JL, Braunlin M, Laversanne M, Valery PC, Bray F, McGlynn KA. International trends in liver cancer incidence, overall and by histologic subtype, 1978-2007. Int J Cancer. 2016;139 (7):1534-1545. doi:10.1002/ijc.30211

96. Xu MD, Wang YQ, Weng WW, et al. A positive feedback loop of lncRNA-PVT1 and FOXM1 facilitates gastric cancer growth and invasion. Clin Cancer Res. 2017;23:2071-2080. doi:10.1158/ 1078-0432.CCR-16-0742

97. Ding C, Yang Z, Lv Z, et al. Long non-coding RNA PVT1 is associated with tumor progression and predicts recurrence in hepatocellular carcinoma patients. Oncol Lett. 2015;9:955-963. doi:10.3892/ol.2014.2730

98. Colombo T, Farina L, Macino G, Paci P. PVT1: a rising star among oncogenic long noncoding RNAs. Biomed Res Int. 2015;2015:1-10. doi:10.1155/2015/304208 
99. Zhang Y, Dang YW, Wang X, et al. Comprehensive analysis of long non-coding RNA PVT1 gene interaction regulatory network in hepatocellular carcinoma using gene microarray and bioinformatics. Am J Transl Res. 2017;9:3904-3917.

100. Song W, Wang K, Zou SB. UCA1 lncRNA in metastases and prognosis. Panminerva Med. 2017;59:278-279. doi:10.23736/ S0031-0808.17.03238-4

101. Wang ZQ, He CY, Hu L, et al. Long noncoding RNA UCA1 promotes tumour metastasis by inducing GRK2 degradation in gastric cancer. Cancer Lett. 2017;408:10-21. doi:10.1016/j. canlet.2017.08.013

102. Qin LT, Tang RX, Lin P, et al. Biological function of UCA1 in hepatocellular carcinoma and its clinical significance: investigation with in vitro and meta-analysis. Pathol Res Pract. 2018;214:1260-1272. doi:10.1016/j.prp.2018.03.025

103. Ni W, Zhang YQ, Zhan ZT, et al. A novel lncRNA uc.134 represses hepatocellular carcinoma progression by inhibiting CUL4A-mediated ubiquitination of LATS1. J Hematol Oncol. 2017;10. doi:10.1186/s13045-017-0449-4

104. Li W, Cooper J, Zhou L, et al. Merlin/NF2 loss-driven tumorigenesis linked to CRL4(DcAF1)-mediated inhibition of the hippo pathway kinases Latsl and 2 in the nucleus. Cancer Cell. 2014;26:48-60. doi:10.1016/j.ccr.2014.05.001

105. Rowland JM. Hepatoblastoma: assessment of criteria for histologic classification. Med Pediatr Oncol. 2002;39:478-483. doi:10.1002/mpo.10171

106. Lv BJ, Zhang LH, Miao RC, et al. Comprehensive analysis and experimental verification of LINC01314 as a tumor suppressor in hepatoblastoma. Biomed Pharmacother. 2018;98:783-792. doi:10.1016/j.biopha.2018.01.013

107. Polireddy K, Chen Q. Cancer of the pancreas: molecular pathways and current advancement in treatment. $J$ Cancer. 2016;7:1497-1514. doi:10.7150/jca.14922

108. Zhang MT, Zhao Y, Zhang YL, et al. LncRNA UCA1 promotes migration and invasion in pancreatic cancer cells via the Hippo pathway. Biochimica Et Biophysica Acta Mol Basis Dis. 2018;1864:1770-1782. doi:10.1016/j.bbadis.2018.03.005

109. Zhou Y, Shan T, Ding W, et al. Study on mechanism about long noncoding RNA MALAT1 affecting pancreatic cancer by regulating Hippo-YAP signaling. J Cell Physiol. 2018;233:5805-5814. doi: $10.1002 /$ jcp. 26357

110. Gao Z-Q, Wang J-F, Chen D-H, et al. Long non-coding RNA GAS5 antagonizes the chemoresistance of pancreatic cancer cells through down-regulation of miR-181c-5p. Biomed Pharmacother. 2018;97:809-817. doi:10.1016/j.biopha.2017.10.157

111. Goodenberger ML, Jenkins RB. Genetics of adult glioma. Cancer Genet. 2012;205:613-621. doi:10.1016/j.cancergen.2012.10.009

112. Stupp R, Taillibert S, Kanner A, et al. Effect of tumor-treating fields plus maintenance temozolomide vs maintenance temozolomide alone on survival in patients with glioblastoma a randomized clinical trial. JAMA. 2017;318:2306-2316. doi:10.1001/jama.2017.18718

113. Wang JC, Quan XY, Peng DT, Hu G. Long non-coding RNA DLEU1 promotes cell proliferation of glioblastoma multiforme. Mol Med Rep. 2019;20:1873-1882. doi:10.3892/mmr.2019.10428

114. Su R, Ma J, Zheng J, et al. PABPC1-induced stabilization of BDNF-AS inhibits malignant progression of glioblastoma cells through STAU1-mediated decay. Cell Death Dis. 2020;11(11). doi:10.1038/s41419-020-2267-9.

115. Bailey TJ, El-Hodiri H, Zhang L, Shah R, Mathers PH, Jamrich M. Regulation of vertebrate eye development by Rx genes. Int J Develop Biol. 2004;48:761-770. doi:10.1387/ijdb.041878tb

116. Nechiporuk T, Klezovitch O, Nguyen L, Vasioukhin V. Dlg5 maintains apical aPKC and regulates progenitor differentiation during lung morphogenesis. Dev Biol. 2013;377:375-384. doi:10. 1016/j.ydbio.2013.02.019
117. Gong W, Zheng J, Liu XB, et al. Knockdown of Long NonCoding RNA KCNQ1OT1 restrained glioma cells' malignancy by activating miR-370/CCNE2 axis. Front Cell Neurosci. 2017; 11. doi: $10.3389 /$ fncel.2017.00084

118. Payton M, Coats S. Cyclin E2, the cycle continues. Int J Biochem Cell Biol. 2002;34:315-320. doi:10.1016/S1357-2725(01)00137-6

119. Wang X, Li XD, Fu ZY, Zhou Y, Huang X, Jiang XB. Long non-coding RNA LINC00473/miR-195-5p promotes glioma progression via YAP1-TEAD1-Hippo signaling. Int $J$ Oncol. 2020;56:508-521. doi:10.3892/ijo.2019.4946

120. Khanna V, Achey RL, Ostrom QT, et al. Incidence and survival trends for medulloblastomas in the United States from 2001 to 2013. J Neurooncol. 2017;135:433-441.

121. Zhang YM, Wang T, Wang S, et al. Nkx2-2as suppression contributes to the pathogenesis of sonic hedgehog medulloblastoma. Cancer Res. 2018;78:962-973. doi:10.1158/0008-5472.CAN-17-1631

122. Farioli-Vecchioli S, Cina I, Ceccarelli M, et al. Tis 21 knock-out enhances the frequency of medulloblastoma in patched 1 heterozygous mice by inhibiting the Cxcl3-dependent migration of cerebellar neurons. $J$ Neurosci. 2012;32:15547-15564. doi:10. 1523/JNEUROSCI.0412-12.2012

123. de Leon AD, Pedrosa I. Imaging and screening of kidney cancer. Radiol Clin North Am. 2017;55:1235-+. doi:10.1016/j.rcl.20 17.06.007

124. Zhang M, Lu W, Huang YQ, et al. Downregulation of the long noncoding RNA TUG1 inhibits the proliferation, migration, invasion and promotes apoptosis of renal cell carcinoma. $J$ Mol Histol. 2016;47:421-428. doi:10.1007/s10735-016-96 83-2

125. Wang PQ, Wu YX, Zhong XD, Liu B, Qiao G. Prognostic significance of overexpressed long non-coding RNA TUG1 in patients with clear cell renal cell carcinoma. Eur Rev Med Pharmacol Sci. 2017;21:82-86.

126. Liu S, Yang YT, Wang WW, Pan XY. Long noncoding RNA TUG1 promotes cell proliferation and migration of renal cell carcinoma via regulation of YAP. $J$ Cell Biochem. 2018;119:9694-9706. doi:10.1002/jcb.27284

127. Hu GH, Dong BB, Zhang JW, et al. The long noncoding RNA HOTAIR activates the Hippo pathway by directly binding to SAV1 in renal cell carcinoma. Oncotarget. 2017;8:58 654-58667. doi:10.18632/oncotarget.17414

128. Siegel RL, Miller KD, Jemal A. Cancer statistics 2019. Ca-a Cancer J Clin. 2019;69:7-34. doi:10.3322/caac.21551

129. Moleirinho S, Hoxha S, Mandati V. et al. Regulation of localization and function of the transcriptional co-activator YAP by angiomotin. Elife;2017. 6. doi:10.7554/eLife.23966

130. Xu Y, Wang KQ, Yu Q. FRMD6 inhibits human glioblastoma growth and progression by negatively regulating activity of receptor tyrosine kinases. Oncotarget. 2016;7:70080-70091. doi:10.18 632/oncotarget. 12148

131. Visser-Grieve S, Hao Y, Yang X. Human homolog of Drosophila expanded, hEx, functions as a putative tumor suppressor in human cancer cell lines independently of the Hippo pathway. Oncogene. 2012;31:1189-1195. doi:10.1038/onc.2011.318

132. Yang Q, Shen XJ, Su ZY, Ju SQ. Emerging roles of noncoding RNAs in multiple myeloma: a review. $J$ Cell Physiol. 2019;234:7957-7969. doi:10.1002/jcp.27547

133. Sun YB, Jiang TX, Jia YQ, Zou JY, Wang XX, Gu WY. LncRNA MALAT1/miR-181a-5p affects the proliferation and adhesion of myeloma cells via regulation of Hippo-YAP signaling pathway. Cell Cycle. 2019;18:2509-2523. doi:10.1080/15384101.2019.1652034

134. Friebele JC, Peck J, Pan X, Abdel-Rasoul M, Mayerson JL. Osteosarcoma: a meta-analysis and review of the literature. $\mathrm{Am}$ J Orthop (Belle Mead NJ). 2015;44:547-553.

135. Wang YJ, Sun BS, Wen X, et al. The roles of lncRNA in cutaneous squamous cell carcinoma. Front Oncol. 2020;10. 
136. Schatz N, Brandlein S, Ruckl K, Hensel F, Vollmers HP. Diagnostic and therapeutic potential of a human antibody cloned from a cancer patient that binds to a tumor-specific variant of transcription factor TAF15. Cancer Res. 2010;70:398-408. doi:10.1158/0008-5472.CAN-09-2186

137. Cabili MN, Trapnell C, Goff L, et al. Integrative annotation of human large intergenic noncoding RNAs reveals global properties and specific subclasses. Genes Dev. 2011;25:1915-1927. doi:10. 1101/gad.17446611

138. Zheng X, Han H, Liu GP, et al. LncRNA wires up Hippo and Hedgehog signaling to reprogramme glucose metabolism. EMBO J. 2017;36:3325-3335. doi:10.15252/embj.201797609

139. Xie M, Zhang L, He CS, et al. Prognostic significance of TAZ expression in resected non-small cell lung cancer. J Thorac Oncol. 2012;7:799-807. doi:10.1097/JTO.0b013e318248240b

140. Wang Y, Dong Q, Zhang Q, Li Z, Wang E, Qiu X. Overexpression of yes-associated protein contributes to progression and poor prognosis of non-small-cell lung cancer. Cancer Sci. 2010;101:1279-1285. doi:10.1111/j.1349-7006.2010.01511.x

141. d'Ydewalle C, Ramos DM, Pyles NJ, et al. The Antisense Transcript SMN-AS1 regulates SMN expression and is a novel therapeutic target for spinal muscular atrophy. Neuron. 2017;93 (1):66-79. doi:10.1016/j.neuron.2016.11.033.

142. Amodio N, Stamato MA, Juli G, et al. Drugging the IncRNA MALAT1 via LNA gapmeR ASO inhibits gene expression of proteasome subunits and triggers anti-multiple myeloma activity. Leukemia. 2018;32:1948-1957. doi:10.1038/s41375-018-0067-3

143. Jin SJ, Jin MZ, Xia BR, Jin WL. Long Non-coding RNA DANCR as an emerging therapeutic target in human cancers. Front Oncol. 2019;9:1225. doi:10.3389/fonc.2019.01225
144. Yu FX, Luo J, Mo JS, et al. Mutant Gq/11 promote uveal melanoma tumorigenesis by activating YAP. Cancer Cell. 2014; 25:822-830. doi:10.1016/j.ccr.2014.04.017

145. Gaspar P, Tapon N. Sensing the local environment: actin architecture and Hippo signalling. Curr Opin Cell Biol. 2014;31:74-83. doi:10.1016/j.ceb.2014.09.003

146. Ehmer U, Sage J. Control of proliferation and cancer growth by the hippo signaling pathway. Mol Cancer Res. 2016;14:127-140. doi:10.1158/1541-7786.MCR-15-0305

147. Maugeri-Sacca M, De Maria R. The Hippo pathway in normal development and cancer. Pharmacol Ther. 2018;186:60-72.

148. Cheetham SW, Gruhl F, Mattick JS, Dinger ME. Long noncoding RNAs and the genetics of cancer. $\mathrm{Br} J$ Cancer. 2013;108:2419-2425. doi:10.1038/bjc.2013.233

149. Peng WX, Koirala P, Mo YY. LncRNA-mediated regulation of cell signaling in cancer. Oncogene. 2017;36:5661-5667. doi:10.1038/onc.2017.184

150. Wu Y, Zhang Y, Qin X, Geng H, Zuo D, Zhao Q. PI3K/AKT/ mTOR pathway-related long non-coding RNAs: roles and mechanisms in hepatocellular carcinoma. Pharmacol Res. 2020;160:105195. doi:10.1016/j.phrs.2020.105195

151. Zarkou V, Galaras A, Giakountis A, Hatzis P. Crosstalk mechanisms between the WNT signaling pathway and long non-coding RNAs. Noncoding RNA Res. 2018;3:42-53. doi:10.1016/j. ncrna.2018.04.001

152. Gong X, Zhu Z. Long noncoding RNA HOTAIR contributes to progression in hepatocellular carcinoma by sponging miR-2175p. Cancer Biother Radiopharm. 2020;35:387-396. doi:10.1089/ cbr.2019.3070

\section{Publish your work in this journal}

OncoTargets and Therapy is an international, peer-reviewed, open access journal focusing on the pathological basis of all cancers, potential targets for therapy and treatment protocols employed to improve the management of cancer patients. The journal also focuses on the impact of management programs and new therapeutic agents and protocols on patient perspectives such as quality of life, adherence and satisfaction. The manuscript management system is completely online and includes a very quick and fair peer-review system, which is all easy to use. Visit http://www.dovepress.com/ testimonials.php to read real quotes from published authors. 